\title{
Extension of methods for jellyfish and ctenophore trophic ecology to large-scale research
}

\author{
Jennifer E. Purcell
}

Published online: 27 September 2008

(C) The Author(s) 2008. This article is published with open access at Springerlink.com

\begin{abstract}
Science has rapidly expanded its frontiers with new technologies in the 20th Century. Oceanography now is studied routinely by satellite. Predictive models are on global scales. At the same time, blooms of jellyfish and ctenophores have become problematic, especially after 1980 . Although we have learned a great deal about gelatinous zooplankton ecology in the 20th Century on local scales, we generally have not scaledup to estimate the extent, the causes, or effects of large blooms. In this age of global science, research on gelatinous zooplankton needs to utilize large-scale approaches and predictive equations. Some current techniques enable jellyfish populations (aerial, towed cameras), feeding (metabolic rates, stable isotopes), and dynamics (predictive modeling) to be studied over large spatial and temporal scales. I use examples of scyphomedusae (Aurelia spp., Cyanea capillata, Chrysaora quinquecirrha) and Mnemiopsis leidyi ctenophores, for which considerable data exist, to explore expanding from local to global scales of jellyfish trophic ecology. Regression analyses showed
\end{abstract}

Guest editors: K. A. Pitt \& J. E. Purcell

Jellyfish Blooms: Causes, Consequences, and Recent Advances

J. E. Purcell $(\bowtie)$

Shannon Point Marine Center, Western Washington

University, 1900 Shannon Point Rd., Anacortes,

WA 98221, USA

e-mail: purcelj3@wwu.edu that feeding rates of Aurelia spp. (FR in copepods eaten medusa ${ }^{-1} \mathrm{~d}^{-1}$ ) generally could be estimated $\pm 50 \%$ from in situ data on medusa wet weight (WW) and copepod density; temperature was not a significant factor. FR of $C$. capillata and C. quinquecirrha were similar to those of Aurelia spp.; the combined scyphomedusa regression underestimated measured FR of C. quinquecirrha and Aurelia spp. by $50 \%$ and $180 \%$, respectively, and overestimated measured FR of $C$. capillata by $25 \%$. Clearance rates (CR in liters cleared of copepods ctenophore ${ }^{-1} \mathrm{~d}^{-1}$ ) of $M$. leidyi were reduced in small containers $(\leq 201)$, and a ratio of container-volume to ctenophore-volume of at least 2,500:1 is recommended for feeding experiments. Clearance rates were significantly related to ctenophore WW, but not to prey density or temperature, and estimated rates within 10-159\%. Respiration rates of medusae and ctenophores were similar across habitats with greatly ambient different temperatures $\left(10-30^{\circ} \mathrm{C}\right)$, and can be predicted from regressions using only mass. These regressions may permit estimation of feeding effects of gelatinous predators without exhaustive collection of feeding data in situ. I recommend that data on feeding and metabolism of jellyfish and ctenophores be entered in a database to allow generalized predictive relationships to be developed to promote inclusion of these important predators in ecosystem studies and models.

Keywords Metabolism - Scaling · Feeding · Global $\cdot$ Model $\cdot$ Methods $\cdot$ Review 


\section{Introduction}

During the 20th Century, we have learned a great deal about the ecology of the predaceous gelatinous zooplankton, including jellyfish (scyphomedusae, cubomedusae, and hydromedusae), siphonophores, and ctenophores. They are ubiquitous in the world's oceans and estuaries, living from the surface to the greatest depths. They affect the food web from microplankton (e.g., Colin et al., 2005) to whales (Purcell et al., in press). Since they can consume large quantities of ichthyoplankton and zooplankton, their potential importance as both predators and competitors of fish is of particular interest to humans.

Blooms of jellyfish and ctenophores have been problematic in coastal water, especially since the 1980s (reviewed in Purcell et al., 2001b, 2007). When great abundances occur, jellyfish can interfere with fishing, kill fish in aquaculture enclosures, clog power and desalination plant water intakes, and cause health concerns for swimmers (Purcell et al., 2007). Mnemiopsis leidyi A. Agassiz ctenophores have caused great damage to fisheries by competing with fish for zooplankton, and eating fish eggs and larvae in the Black Sea, where they were accidentally introduced in the early 1980s. The ctenophores spread to the Azov, Caspian, Marmara, and Mediterranean seas, and recently (2006), were discovered in the North and Baltic seas (e.g., Boersma et al., 2007). Generally, jellyfish and ctenophore blooms are detrimental to human enterprise.

Jellyfish and ctenophore blooms occur over broad regions, such as in the Black, Azov, and Caspian seas (e.g., Shiganova et al., 2003), the Mediterranean Sea (Bernard et al., 1988; Goy et al., 1989), Gulf of Mexico (Graham et al., 2003a, b), the Seto Inland Sea of Japan (Uye et al., 2003), and the East Asian Marginal Seas (Uye, 2008). In spite of their importance and our increased knowledge, few attempts have been made to estimate population trends or the effects of jellyfish blooms on plankton food webs. In order to study the effects of jellyfish blooms, researchers need to utilize large-scale methods for estimating jellyfish and ctenophore size, abundances, and their predation effects.

In large-scale research, some error is inevitable, which is against our training for accuracy and precision as scientists. Nevertheless, atmospheric and oceanographic scientists now routinely study the Earth from satellite data. For example, estimation of sea surface chlorophyll $a(\mathrm{Chl} a)$ is derived from algorithms based on properties of light reflected from the sea surface, as measured by satellite (SeaWiFS). Empirical measurements of Chl $a$ from ocean water, as typically measured by fluorescence, show significant deviation from the satellite estimates, but this widely used method provides global estimates of production (e.g., Marrari et al., 2006).

Because of large sizes, fragility, and non-dispersed distributions, many gelatinous zooplankton species present problems both for field sampling and laboratory experiments, which have limited research efforts on them as compared with the more robust crustaceans (e.g., Raskoff, 2003). The relatively abundant data for copepods have enabled development of algorithms for predicting their feeding, growth, fecundity, and mortality rates in relation to Chl $a$, temperature, and size (e.g., Hansen et al., 1997; Hirst \& Bunker, 2003; Bunker \& Hirst, 2004; Hirst \& Kiørboe, 2002; Hirst et al., 2003). Unfortunately, such data are much more limited for gelatinous species than for copepods, and few predictive algorithms have been developed (see Palomares \& Pauly, 2008).

In this article, I review recent use of large-scale methods of data collection for jellyfish and ctenophore size and abundances, and explore developing algorithms to estimate feeding effects so that localscale knowledge can be expanded to large-scale research. These recommendations are intended to promote research on gelatinous zooplankton by utilizing standard methods and existing knowledge.

\section{Large-scale techniques to determine jellyfish and ctenophore population sizes}

Net-sampling

Data on the abundances of jellyfish and ctenophores are basic to research on their ecological importance. Gelatinous zooplankton presents many challenges for sampling (Raskoff, 2003). The traditional method of quantitative sampling of zooplankton and nekton by nets with flow-meters and preservation in formalin is inappropriate for many jellyfish and ctenophores that are large, sparsely or unevenly distributed, or delicate. 
Net sampling is often adequate for small, abundant hydromedusae and calycophoran siphonophores (e.g., Pagès et al., 1996a, b; Hosia \& Båmstedt, 2007), and some robust ctenophores, specifically, Pleurobrachia spp., Mertensia ovum (Fabricius), Beroe spp., and with care, Mnemiopsis leidyi (e.g., Purcell, 1988; Siferd \& Conover, 1992; Shiganova et al., 2003). Large species require a large sampling volume and larger nets; semi-quantitative sampling of scyphomedusae and large hydromedusae is possible with fish and shrimp trawls and seines (e.g., Brodeur et al., 1999, 2002, 2008a, b; Graham, 2001; Purcell, 2003). A single method is typically adequate for only one type within a mixture of taxa (e.g., scyphomedusae, hydromedusae, and ctenophores).

National and state fisheries services usually have annual stock surveys that sample with large trawls, cover large regions, and have been conducted for decades. Such stock surveys have provided invaluable data on jellyfish populations, when their numbers or biomass have been documented from the by-catch. Important contributions include data on Chrysaora melanaster Brandt in the eastern Bering Sea (Brodeur et al., 1999, 2002, 2008a), Chrysaora quinquecirrha (Desor) and Aurelia aurita (Linné) in the Gulf of Mexico (Graham, 2001), Chrysaora hysoscella Eschscholtz, A. aurita, and Cyanea capillata (Linné) in the North Sea (Lynam et al., 2004, 2005), and Nemopilema nomuri (Kishinouye) around Japan (Uye, 2008). It would be virtually impossible for individual researchers to sample over the extensive spatial and temporal scales of governmentsponsored fisheries programs. For example, annual surveys in the Bering Sea comprised 356 stations over 27 years (Brodeur et al., 2008a). This sampling is semi-quantitative because fisheries do not target jellyfish and fish catch is standardized only as Catch Per Unit Effort (CPUE). Unfortunately, not all fisheries sampling quantifies jellyfish by-catch. Thus, fish trawls are reasonable for sampling large, robust gelatinous species. This sampling is inadequate for small and delicate species, which pass through the large meshes or are destroyed.

\section{Other animals as samplers}

An ingenious method of determining the large-scale distribution of gelatinous species has been by use of their predators as samplers (Link \& Ford, 2006).
Many fish eat gelatinous species (e.g., Arai, 2005), and gut analyses routinely are performed on commercial fish species during the annual surveys. Link $\&$ Ford (2006) used a large-scale dataset that showed a long-term (1980-2000) increase of ctenophores in the fresh stomach contents of spiny dogfish, Squalus acanthius Linnaeus, off the U. S. North Atlantic coast. This method does not yet yield quantitative data on jellyfish or ctenophore abundance as well as feeding rates, but could be improved with knowledge of coincident abundances and digestion times of gelatinous species in the predators' stomachs (Arai et al., 2003).

Satellite and electronic tracking, and acoustic sampling

Use of predators as samplers might allow location of gelatinous organisms by satellite. Leatherback turtles feed almost exclusively on gelatinous zooplankton and can be routinely tracked by satellite tags (Benson et al., 2007); areas where their tracks are concentrated may indicate jellyfish aggregations. Collaborations between sea turtle and jellyfish researchers would produce important data for both (e.g., Houghton et al., 2006; Witt et al., 2007).

Various attempts have been made to tag jellyfish with fish tags, with limited success. Difficulty arises because the tags sink the jellyfish and migrate out of the gelatinous tissue. Recent successful studies show movements of Chironex fleckeri Southcott cubomedusae (Seymour et al., 2004; Gordon \& Seymour, 2008). Time-at-depth recorders (TDRs) were glued to the large, rigid swimming bells of these medusae. A TDR was attached by a cable tie to Chrysaora hysoscella medusae, which enabled their vertical movements to be tracked (Hays et al., 2008). As tags become increasingly smaller and less expensive, such methods should become more widely applicable.

Acoustics routinely are used to estimate fish abundance, and can estimate jellyfish population abundances as well (e.g., Båmstedt et al., 2003; Brierley et al., 2004; Lynam et al., 2006; Kaartvedt et al., 2007; Colombo et al., 2003, 2008). The most extensive work has been in the Namibian Benguela Current, where distributions and biomass of Chrysaora hysoscella and Aequorea forskalea Peron \& Lesueur jellyfish, Cape horse mackerel, and clupeids were estimated with multifrequency acoustics 
(Lynam et al., 2006). Validation of acoustic sampling for robust $P$. periphylla Peron \& Lesueur showed that small medusae were missed by this method, but that large ones were detected individually (Båmstedt et al., 2003). Difficulties with acoustical methods would be encountered for flaccid species that do not reflect the acoustic signals well and associated fish confound the acoustic signals. Depth-discrete net sampling should be used to determine the species, sizes, and relative abundances of the fish and jellyfish components of the scattering layers.

\section{Continuous plankton recorder (CPR) surveys}

Extensive CPR sampling has been conducted for decades in the North Sea and North Atlantic, and part of the sample analysis includes counting nematocysts. Attrill et al. (2007) documented a positive relationship between jellyfish (nematocysts) in the North Sea and climatic factors (the North Atlantic Oscillation Index, NAOI) during 1958-2000. Gelatinous records from the CPR were used to identify favorable leatherback turtle habitat (Witt et al., 2007). Analysis of cnidarian abundance in CPR data showed that seasonal and decadal patterns, and cnidarian relationships with climate and food indicators differed in the shelf and oceanic regions of the North Atlantic Ocean from 1946 to 2005 (Gibbons \& Richardson, 2008). Limitations of the CPR data are that they are from surface waters only and the identities of the nematocyst-bearers are unknown; however, CPR data are collected on vessels of opportunity over vast ocean regions, and the data provide a mostly untapped source of data on cnidarians. Currently, molecular analysis of CPR samples (Kirby \& Lindley, 2005) is aiding in identification of soft tissues (Cnidaria and Chordata; P. Licandro, SAHFOS, personal communication).

\section{Video surveys}

A towed video-recording system has been used to quantify scyphomedusae and ctenophores relative to environmental conditions (depth, temperature, salinity, dissolved oxygen, and chlorophyll) in the Gulf of Mexico (Purcell et al., 2001a; Graham et al., 2003b). Densities and distributions relative to the physical conditions can be measured vertically as well as over long horizontal distances. Densities estimated with the video system agreed well ( $<40 \%$ difference) with those from a Tucker trawl for medusae $>15 \mathrm{~cm}$ in diameter (Graham et al., 2003b).

Remotely Operated Vehicles (ROVs) have been used for semi-quantitative sampling of gelatinous species (e.g., Raskoff, 2001; Båmstedt et al., 2003; Raskoff et al., 2005). Because ROVs allow study at great depths, most work has been on deep-living species. Both horizontal and vertical transecting has been conducted. Methods such as nearest-neighbor distances (Mackie \& Mills, 1983) and apparent size vs. visible volume (Båmstedt et al., 2003) have been used to estimate densities. Paired lasers allow size calculation. If only the duration of viewing is known, the relative abundances of organisms can be determined (e.g., Raskoff et al., 2005, in press). ROV abundance estimates of $P$. periphylla medusae were roughly twice those from a WP3 net $\left(0.8 \mathrm{~m}^{2}\right.$ mouth area; Båmstedt et al., 2003).

\section{Ocean-surface surveys}

When in situ sampling is not possible, visual observations from the surface can yield data on large-scale distributions of large jellyfish (Sparks et al., 2001; Doyle et al., 2007). Doyle et al. (2007) counted large scyphomedusae along regular ferry routes across the Irish and Celtic seas, which provided relative distributions and abundances among species and years. The distances from the ship that jellyfish were visible in different sea-states were determined to ensure comparability of counts. Surface data could be compared with concurrent trawl data in order to convert surface counts to estimated jellyfish abundance in the water column.

\section{Shore-based surveys}

Some of the longest records of jellyfish occurrence have been from shore-based surveys. Daily counts from a pier in Chesapeake Bay for 30 years showed that Chrysaora quinquecirrha scyphomedusae were most abundant in years of low freshwater input and warm spring temperatures (Cargo \& King, 1990). Sting reports from beaches can provide long-term and large-scale records, such as for Pelagia noctiluca (Forskal) in the Mediterranean Sea (Bernard et al., 1988). Jellyfish strandings along the Irish and Celtic seacoasts provided data on the relative distributions, 
abundances, seasonality, and inter-annual variation among scyphomedusan species (Doyle et al., 2007; Houghton et al., 2007). Above-water video has been used to track in situ aggregations of Aurelia aurita jellyfish (Fuji et al., 2007), and this technique could be applied for beach stranding surveys.

\section{Aerial surveys}

Near-surface jellyfish aggregations and large jellyfish can be quantified from aerial surveys (e.g., Purcell et al., 2000; Houghton et al., 2006). The numbers of Aurelia labiata Chamisso and Eysenhardt aggregations showed great inter-annual variation in Prince William Sound, Alaska, where between 28 and 770 occurred in 1995-1998 (Purcell et al., 2000). Flightpath and targets were recorded by use of a hand-held GPS connected to a laptop computer with a flight log program. The sizes and numbers of the aggregations allowed estimation of surface areas. Details of the aerial methodology are in Brown et al. (1999). Individual Cyanea capillata medusae also were visible from the plane. Densities of jellyfish could be estimated if aerial data were combined with in situ sampling of jellyfish densities in the aggregations (e.g., Uye et al., 2003). Aerial surveys can cover large areas at low cost in comparison with sea-going surveys. Fish schools, marine vertebrates, and birds can also be quantified by aerial surveys (Brown et al., 1999; Houghton et al., 2006).

Modeling of jellyfish population dynamics and ecosystem effects

Key objectives are to understand the causes of variation in jellyfish and ctenophore population sizes, to predict future population sizes, and to estimate their trophic importance. Inter-annual variation in jellyfish occurrence and spatial distribution in relationship to climatic variables have shown associations of large populations with high temperature and salinity for Pelagia noctiluca in the Mediterranean Sea (Goy et al., 1989; Molinero et al., 2005) and Chrysaora quinquecirrha medusae in Chesapeake Bay (Cargo \& King, 1990; Brown et al., 2002; Decker et al., 2007). Generalized additive models (GAM) allow non-linear analysis of variables, which showed the largest populations of Chrysaora melanaster medusae occurred in years with moderate temperatures and ice cover in the Bering Sea; biotic variables, such as zooplankton, and fish biomass, were also incorporated into the models (Brodeur et al., 2008a). While such models identify possible causes of past jellyfish blooms, they also enable prediction of abundances in future conditions (Goy et al., 1989; Cargo \& King, 1990; Decker et al., 2007).

To my knowledge, similar models have not been developed yet for any ctenophore species; however, Kremer (1976) used an energetics model for Mnemiopsis leidyi to predict seasonal population dynamics from the measurements of clearance, metabolic, reproduction, and assimilation rates. The model used temperature and zooplankton abundance as forcing functions to estimate population changes. The model later was coupled with a deterministic simulation model for Naragansett Bay, in which zooplankton biomass was not forced (Kremer \& Kremer, 1982).

Several ecosystem models have incorporated jellyfish or ctenophores (e.g., Baird \& Ulanowicz, 1989; Oguz et al., 2001; Oguz, 2005a, b; Ruzicka et al., 2007; reviewed in Pauly et al., 2008). Generally, such efforts suffer from insufficient information on jellyfish biomass and biology (Pauly et al., 2008). Prediction of the responses of jellyfish and ctenophore populations to the multiple changes occurring in the global ocean makes obtaining the necessary data for such modeling studies of great importance.

\section{Use of feeding data to estimate jellyfish and ctenophore predation on large scales}

The diets and predation rates of many gelatinous species have been detailed since the 1970s. Although previously thought to be generalists, most species show various degrees of selectivity (reviewed in Purcell, 1997). Knowledge of such dietary differences is necessary for understanding the roles of jellyfish and ctenophores in the food web. In addition to mesozooplankton and ichthyoplankton, they eat microplankton (e.g., Stoecker et al., 1987a, b; Sullivan \& Gifford, 2004; Colin et al., 2005), gelatinous species (reviewed in Purcell, 1997), and emergent zooplankton (Pitt et al., 2008a).

Stable isotope and fatty acid analyses are being used to follow the transfer of the organic matter through the food webs and to understand trophic 
relationships of gelatinous species (reviewed in Pitt et al., 2008b). Stable isotopes showed that Catostylus mosaicus (Quoy and Gaimard) medusae heavily utilized emergent zooplankton, and would be important contributors to benthic-pelagic coupling (Pitt et al., 2008a). Stable isotopes show that Aurelia spp. have a lower trophic level than other scyphomedusae (Kohama et al., 2006; Brodeur et al., 2008b), indicating use of microplankton by this genus, which blooms in eutrophic waters around the world. Similarly, Mnemiopsis leidyi ctenophores bloom in eutrophic waters, and the diets of young ctenophores $<1 \mathrm{~cm}$ length contain high percentages of microplankton (Sullivan \& Gifford, 2004; Rapoza et al., 2006), although stable isotope analysis of large M. leidyi did not indicate extensive consumption of microplankton (Montoya et al., 1990). The interactions of pelagic cnidarians and ctenophores with microplankton communities generally have been seldom studied (except Pitt et al., 2007, 2008b, c), and this may be especially important for the problem species Aurelia spp. and M. leidyi in eutrophic waters. Neither stable isotope nor fatty acid analyses provide quantitative feeding rates; however, feeding with ${ }^{14} \mathrm{C}$-labeled prey can provide information about the amount of $\mathrm{C}$ assimilated (Pitt et al., 2008c).

Feeding rates (FR) of gelatinous species have been estimated by several methods, including prey removal in laboratory containers, in situ gut contents with digestion times, and metabolic rates to indicate minimum (reviewed in Purcell, 1997). Containers generally reduce FR of even small species, and metabolic rates yield minimum consumption estimates; hence, the gut-content method usually gives the highest feeding estimates. While the gut-content method may be most representative of FR on mesozooplankton in situ, it is very labor intensive and time-consuming, and inaccurate for species eating microplankton.

Few studies compare results obtained by the different methods to estimate feeding. FR of Pleurobrachia sp. ctenophores estimated by the gut content method always were higher than estimates by the clearance method (in 1,300-1 mesocosms; Sullivan \& Reeve, 1982). Comparisons for several siphonophore species showed that gut-content estimates were higher than metabolic estimates for large species, but similar for small species, and that clearance rates generally gave the lowest FR estimates (Mackie et al., 1987). In situ ingestion (gut-contents) was similar to laboratory ingestion at low prey densities $\left(5 \mathrm{l}^{-1}\right)$; specific ingestion in situ $\left(2 \% \mathrm{~d}^{-1}\right)$ was similar to specific metabolism $\left(3 \% \mathrm{~d}^{-1}\right)$ for the small siphonophore Sphaeronectes gracilis (Claus) (Purcell $\&$ Kremer, 1983). Specific rations of the scyphomedusan Linuche unguiculata (Swartz), as estimated by gut contents and feeding experiments, were within a factor of two (Kremer, 2005).

Several generalizations result from previous studies (Purcell, 1997). One is that the main prey of most jellyfish and ctenophore species is copepods. A second is that feeding rates increase in proportion to predator size and prey density. A third is that digestion times are inversely correlated with temperature. Therefore, I hypothesize that the feeding rates can be predicted by multiple regressions of predator size, prey densities, and temperature.

\section{Scyphomedusae}

I tested the above hypothesis for scyphomedusae by use of raw data from previous studies on the numbers of copepods in field-collected medusae, medusa size (wet weight (WW) in g), prey density (PD in copepods $\mathrm{m}^{-3}$ ), and temperature $\left(\mathrm{T}\right.$ in $\left.{ }^{\circ} \mathrm{C}\right)$, in combination with digestion times and medusa size conversions in those publications, to calculate feeding rates (FR in copepods eaten medusa ${ }^{-1} \mathrm{~d}^{-1}$ ). I restricted the analyses to studies in which individual medusae were collected by dip net or by SCUBA divers. I added 1 to all gut content data so that zero feeding would not be lost from the analyses. All data, except temperature, were $\log _{10}$ transformed, after which the data met normaldistribution and constant-variance assumptions of the analyses. Outliers greater than 2 standard deviations were identified by studentized residuals and removed from each dataset. Pearson's product moment correlations tested for correlations among all variables. Collinearity was evaluated by means of VIF and Durbin-Watson $(\mathrm{D}-\mathrm{W})$ statistics; VIF values $\approx 1$ and $\mathrm{D}-\mathrm{W}$ values $\approx 2$ were acceptable. First, I tested Aurelia spp. from habitats differing in medusa size (0.005-1,139 g wet weight), prey densities (38874,222 copepods $\left.\mathrm{m}^{-3}\right)$, and temperature $\left(9-31^{\circ} \mathrm{C}\right)$. Data for Aurelia spp. were from July 1998 and 1999 in Prince William Sound, Alaska (PWS), March-April 1991 in Southampton water, United Kingdom (UK), August 1991 and May-6 August in the Inland Sea, Japan (ISJ), and May 1997 in Ngermeaungel Lake, 
Koror, Palau (NLK); previous analyses are in Purcell (2003), C. H. Lucas (unpublished), Uye \& Shimauchi (2005), and Dawson \& Martin (2001), respectively. Then, I compared Aurelia spp. with two other species, Chrysaora quinquecirrha from June -August 1987, June-September 1988 and 1989, August 1990, and July 1991 in Chesapeake Bay, USA (CB; Purcell, 1992) and Cyanea capillata from July 1998 and 1999 in PWS (Purcell, 2003).

\section{Aurelia spp.}

Pearson correlations showed that all variables (FR, T, $\mathrm{WW}$, and PD) were correlated in nearly every combination (Table 1). This is reasonable biologically

Table 1 Pearson product moment correlations of medusa wet weight (WW), prey density (PD), and temperature (T) with the feeding rate (FR; numbers of copepods eaten medusa ${ }^{-1} \mathrm{~d}^{-1}$ )

\begin{tabular}{|c|c|c|}
\hline \multirow[t]{2}{*}{ Pair of variables } & \multicolumn{2}{|c|}{ Pearson's correlation } \\
\hline & $R$ & $P$ \\
\hline $\mathrm{FR}_{\text {PWS }}$ vs. WW $\mathrm{WWS}_{\mathrm{PW}}$ & 0.750 & $1.20 \times 10^{-11}$ \\
\hline FR $_{\text {PWs }}$ vs. PD PWs & 0.121 & 0.364 \\
\hline WW $_{\text {PWs }}$ vs. PD PWs & 0.247 & -0.154 \\
\hline $\mathrm{FR}_{\mathrm{UK}}$ vs. $\mathrm{WW}_{\mathrm{UK}}$ & 0.456 & $8.20 \times 10^{-5}$ \\
\hline FR $_{\mathrm{UK}}$ vs. $\mathrm{PD}_{\mathrm{UK}}$ & 0.348 & 0.003 \\
\hline FR $_{U K}$ vs. $T_{U K}$ & 0.329 & 0.006 \\
\hline $\mathrm{WW}_{\mathrm{UK}}$ vs. $\mathrm{PD}_{\mathrm{UK}}$ & 0.236 & 0.051 \\
\hline $\mathrm{WW}_{\mathrm{UK}}$ vs. $\mathrm{T}_{\mathrm{UK}}$ & 0.225 & 0.062 \\
\hline $\mathrm{PD}_{\mathrm{UK}}$ vs. $\mathrm{T}_{\mathrm{UK}}$ & 0.832 & $8.84 \times 10^{-19}$ \\
\hline FR $_{\text {ISJ }}$ vs. $\mathrm{WW}_{\text {ISJ }}$ & 0.604 & $5.02 \times 10^{-8}$ \\
\hline FR $_{\text {ISJ }}$ vs. $\mathrm{PD}_{\text {ISJ }}$ & 0.521 & $5.21 \times 10^{-6}$ \\
\hline FRR ISJ $_{\text {vs. }} \mathrm{T}_{\text {ISJ }}$ & 0.367 & 0.002 \\
\hline $\mathrm{WW}_{\text {ISJ }}$ vs. $\mathrm{PD}_{\text {ISJ }}$ & 0.399 & $<0.001$ \\
\hline $\mathrm{WW}_{\text {ISJ }}$ vs. $\mathrm{T}_{\text {ISJ }}$ & 0.472 & $4.90 \times 10^{-5}$ \\
\hline PD ISJ vs. $_{\text {ISJ }}$ & 0.551 & $1.15 \times 10^{-6}$ \\
\hline $\mathrm{FR}_{\mathrm{NLK}}$ vs. $\mathrm{WW}_{\mathrm{NLK}}$ & 0.755 & $7.75 \times 10^{-28}$ \\
\hline FR $_{\text {NLK }}$ vs. $P D_{\text {NLK }}$ & -0.126 & 0.131 \\
\hline $\mathbf{W W}_{\mathrm{NLK}}$ vs. PD $_{\mathrm{NLK}}$ & 0.015 & 0.862 \\
\hline FR $_{\text {AUR }}$ vs. $W_{\text {AUR }}$ & 0.550 & $2.67 \times 10^{-28}$ \\
\hline FR $_{\text {AUR }}$ vs. PD $_{\text {AUR }}$ & -0.042 & 0.435 \\
\hline FR $_{\text {AUR }}$ vs. $T_{\text {AUR }}$ & 0.184 & $<0.001$ \\
\hline $\mathbf{W W}_{\text {AUR }}$ vs. $\mathbf{P D}_{\text {AUR }}$ & 0.089 & 0.101 \\
\hline $\mathrm{WW}_{\mathrm{AUR}}$ vs. $\mathrm{T}_{\mathrm{AUR}}$ & 0.354 & $1.70 \times 10^{-11}$ \\
\hline PD $_{\text {AUR }}$ vs. $T_{\text {AUR }}$ & 0.469 & $4.92 \times 10^{-20}$ \\
\hline
\end{tabular}

Table 1 continued

\begin{tabular}{|c|c|c|}
\hline \multirow[t]{2}{*}{ Pair of variables } & \multicolumn{2}{|c|}{ Pearson's correlation } \\
\hline & $R$ & $P$ \\
\hline FR $_{\text {CYA }}$ vs. WW & -0.0231 & 0.775 \\
\hline FR $_{\text {CYA }}$ vs. PD $_{\text {CYA }}$ & 0.463 & $1.14 \times 10^{-9}$ \\
\hline $\mathrm{WW}_{\mathrm{CYA}}$ vs. $\mathrm{PD}_{\mathrm{CYA}}$ & -0.178 & 0.026 \\
\hline FR $_{\mathrm{CHR}}$ vs. $\mathrm{WW}_{\mathrm{CHR}}$ & 0.547 & $1.59 \times 10^{-31}$ \\
\hline FR $_{\mathrm{CHR}}$ vs. $\mathrm{PD}_{\mathrm{CHR}}$ & 0.207 & $4.13 \times 10^{-5}$ \\
\hline FR $_{\text {CHR }}$ vs. $T_{\text {CHR }}$ & -0.026 & 0.614 \\
\hline $\mathrm{WW}_{\mathrm{CHR}}$ vs. $\mathrm{PD}_{\mathrm{CHR}}$ & 0.109 & 0.032 \\
\hline $\mathrm{WW}_{\mathrm{CHR}}$ vs. $\mathrm{T}_{\mathrm{CHR}}$ & -0.145 & 0.004 \\
\hline PD $_{\text {CHR }}$ vs. $T_{\text {CHR }}$ & -0.058 & 0.258 \\
\hline $\mathrm{FR}_{\mathrm{SCY}}$ vs. $\mathrm{WW}_{\mathrm{SCY}}$ & 0.543 & $7.77 \times 10^{-69}$ \\
\hline FR $_{\text {SCY }}$ vs. PD $_{\text {SCY }}$ & -0.028 & 0.406 \\
\hline $\mathrm{FR}_{\mathrm{SCY}}$ vs. $\mathrm{T}_{\mathrm{SCY}}$ & 0.130 & $<0.001$ \\
\hline $\mathrm{WW}_{\mathrm{SCY}}$ vs. $\mathrm{PD}_{\mathrm{SCY}}$ & -0.098 & 0.004 \\
\hline $\mathrm{WW}_{\mathrm{SCY}}$ vs. $\mathrm{T}_{\mathrm{SCY}}$ & 0.081 & 0.016 \\
\hline $\mathrm{PD}_{\mathrm{SCY}}$ vs. $\mathrm{T}_{\mathrm{SCY}}$ & 0.376 & $5.91 \times 10^{-31}$ \\
\hline $\mathrm{DT}_{\mathrm{AUR}}$ vs. $\mathrm{T}_{\mathrm{AUR}}$ & -0.588 & 0.002 \\
\hline $\mathrm{DT}_{\mathrm{AUR}}$ vs. $\mathrm{WW}_{\mathrm{AUR}}$ & -0.408 & $<0.05$ \\
\hline $\mathrm{T}_{\mathrm{AUR}}$ vs. $\mathrm{WW}_{\mathrm{AUR}}$ & 0.548 & 0.004 \\
\hline
\end{tabular}

$R=$ correlation coefficient; $P$, probability; $P>0.05$ are not significant (marked in bold). Data on Aurelia spp. are from Prince William Sound, Alaska (PWS; Purcell, 2003), Southampton, United Kingdom (UK; Lucas, unpublished), the Inland Sea, Japan (ISJ; Uye \& Shimauchi, 2005), and Palau (NLK; Dawson \& Martin, 2001). AUR, combined Aurelia spp.; CHR, Chrysaora quinquecirrha (from Purcell, 1992); CYA, Cyanea capillata (from Purcell, 2003). SCY, combined scyphozoan species. Digestion times (DT) also were tested against WW and $\mathrm{T}$

because after ephyrae are produced in early spring, temperature, prey density, and jellyfish size increase. Temperature was not variable in two cases (PWS and NLK). Where temperature varied (UK, ISJ, and Aurelia spp. combined), it was positively correlated with WW and PD; WW was positively correlated with PD. FR generally had much stronger correlations with the other variables (T, WW, and PD) than correlations among those variables.

Because T, WW, and PD logically could affect medusa feeding rates, I conducted multiple regression analyses (Table 2). VIF and D-W statistics showed that multicollinearity existed when all predictor variables (T, WW, and PD) were tested against the dependent variable (FR). Temperature either did not 


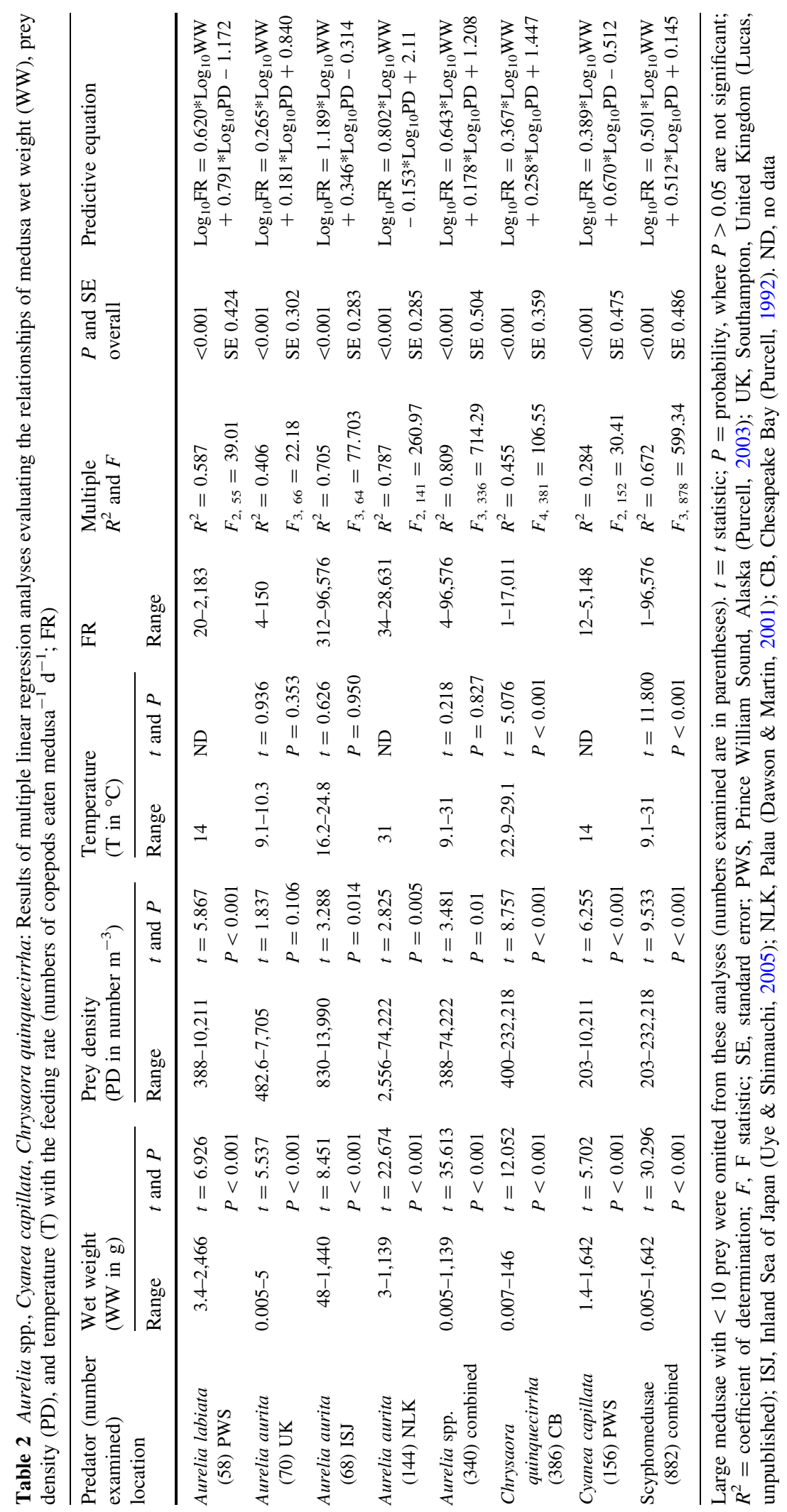


vary or was not significant (Table 2), and multicollinearity was resolved by the removal of temperature from the predictive regressions.

Feeding rates on copepods by Aurelia spp. showed great variability, but were strongly correlated with medusa size and prey density, but not temperature (Table 2, Fig. 1). WW had stronger effects on FR in all cases than PD. In the Inland Sea of Japan (ISJ), the copepods were mainly $(85.6 \%)$ cyclopoids (Oithona spp.), and medusae there, especially large ones, showed greater feeding than other locations where calanoid copepods predominated (80-100\%) (Fig. 1). Southampton (UK) had the smallest medusae, the coolest temperatures, and lowest feeding. Although the Palau marine lake (NLK) had higher prey densities than Japan (ISJ), medusa feeding was lower in NLK, presumably because of smaller medusa size and warmer temperatures.

The reliability of predicting FR is of key importance. The predicted residual error sum of squares (PRESS) statistic indicates how well a regression predicts new data, with small values $(>0)$ being best (SPSS, 1997). The PRESS statistics indicated that all local regressions would be reasonable predictors of feeding; however, the combined equation $($ PRESS $=87.1)$ was a relatively worse predictor (Table 3). In order to test the predictions by the regressions vs. the measured feeding rate data, I entered WW and PD from each dataset into their own (local) and combined regressions (Table 3). Measured Aurelia spp. data in local regressions underestimated feeding by $14-45 \%$. The combined regression overestimated measured FR for PWS medusae by $92 \%$. FR of UK and NLK medusae were predicted well by the combined regression; however, FR of the ISJ medusae estimated by the combined regression was only one-fifth of the measured rate. This poor result for ISJ was probably due to the different prey available (small Oithona spp. in ISJ but mostly calanoids in PWS, UK, and NLK). Therefore, except for ISJ, where prey differed dramatically from other habitats, the combined Aurelia spp. regression estimated feeding rates as well as did the regressions derived from local data.

I also tested measured FR data for Aurelia spp. that had not been used to develop the regressions ('novel') against values calculated from the regressions equations. Results for A. aurita in Taiwan (Lo $\&$ Chen, 2008) differed depending on the net mesh
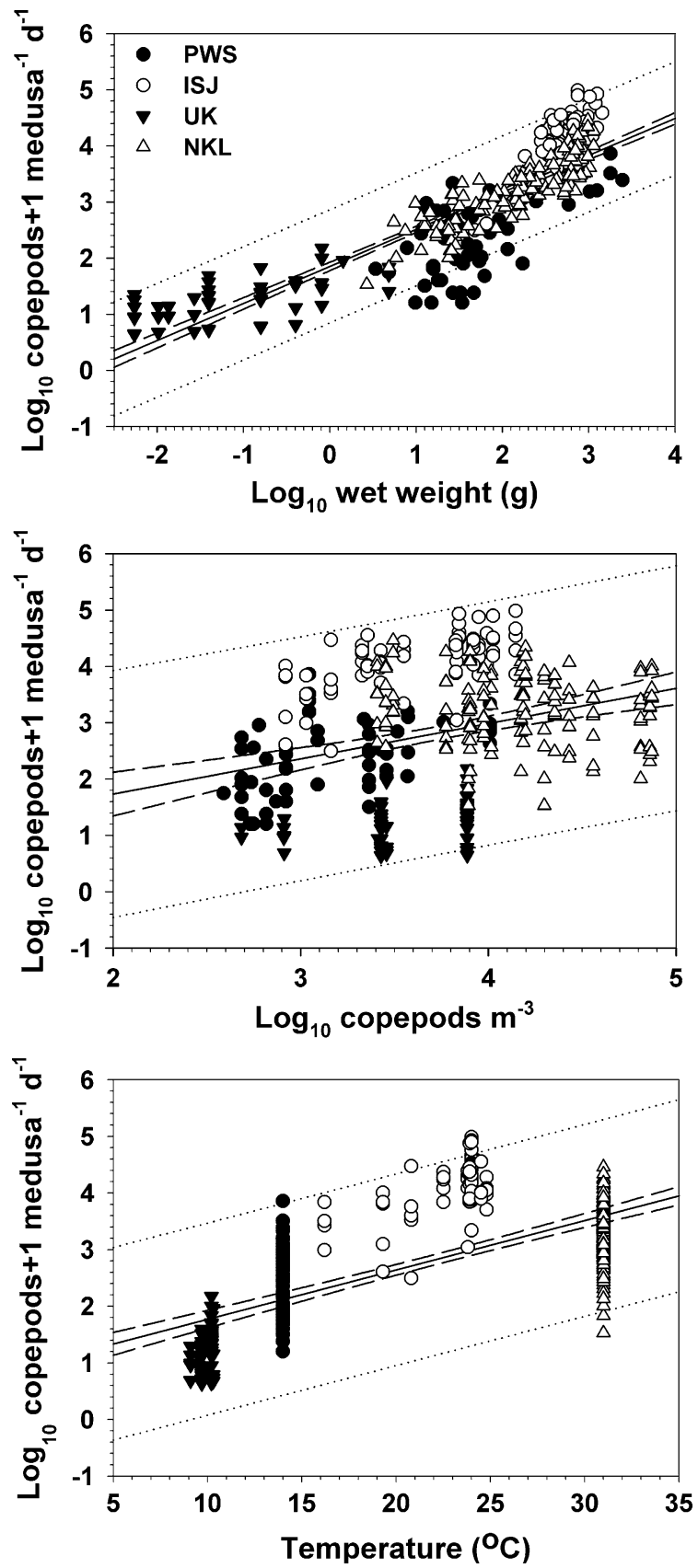

Fig. 1 Feeding rates $\left(\log _{10}\right.$ number of copepods +1 eaten $\mathrm{d}^{-1}$ ) of individual scyphomedusae (Aurelia spp.) from field gut contents vs. medusa wet weight (top), prey density (middle), and temperature (bottom). Medusae were collected from Prince William Sound, Alaska (PWS; Purcell, 2003), the Inland Sea, Japan (ISJ; Uye \& Shimauchi, 2005), Southampton waters, United Kingdom (UK; C.H. Lucas, unpublished), and Ngermeaungel Lake, Koror, Palau (NLK; Dawson \& Martin, 2001). Lines are: solid, linear regressions; dashed, 95\% confidence intervals; dotted, prediction errors 


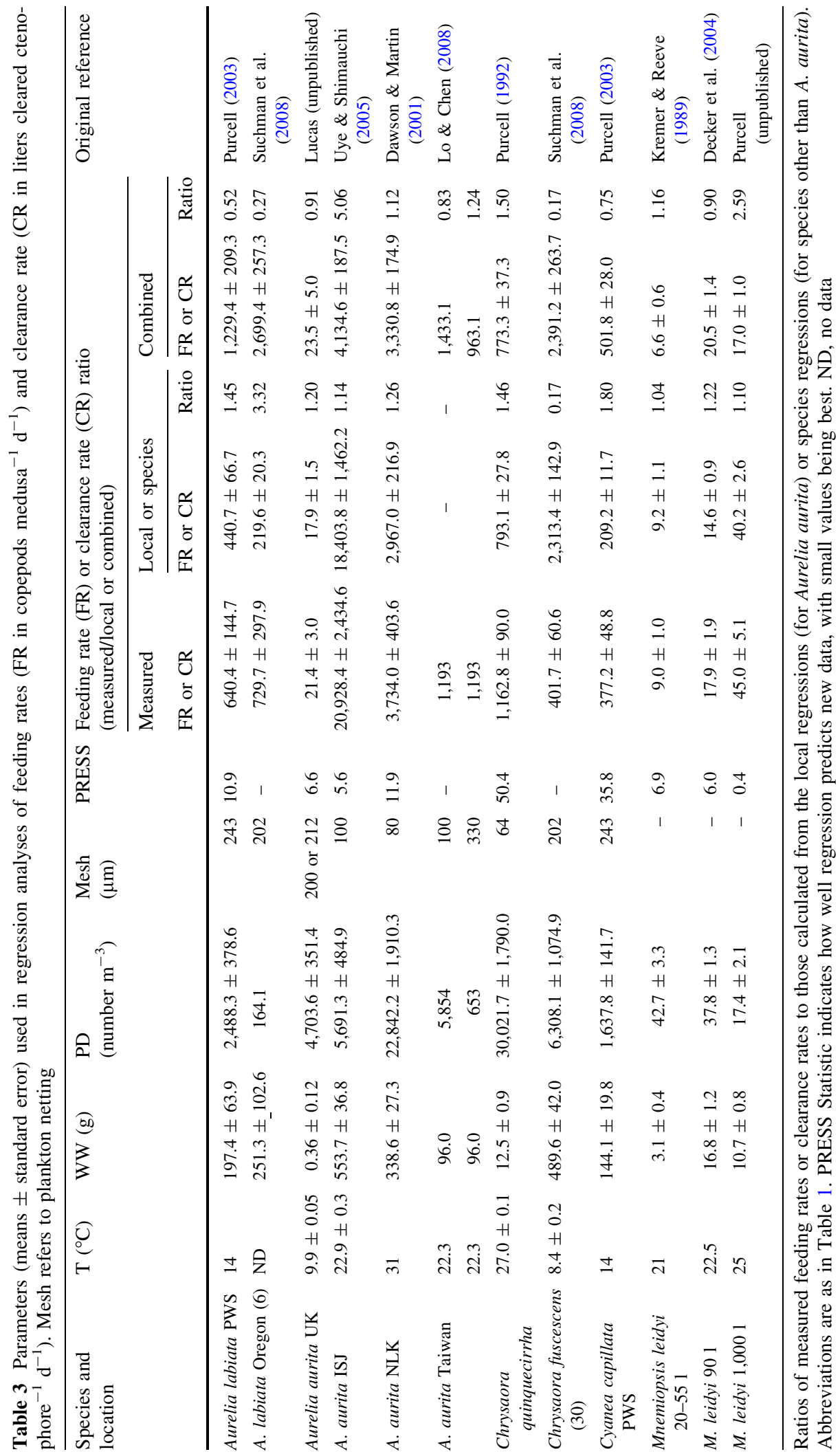


size used for zooplankton data. Use of mean values of in situ variables, including $100-\mu \mathrm{m}$ copepod data, in the combined Aurelia spp. regression underestimated the measured FR by $20 \%$, and use of $330-\mu \mathrm{m}$ copepod data overestimated measured FR by $24 \%$ (Table 3). The mean FR of Aurelia labiata medusae off the Oregon coast was 3.3 times that predicted by the PWS regression, and only $27 \%$ of that predicted by the combined Aurelia spp. regression. Those differences may be due to the low FR of PWS A. labiata relative to the Aurelia spp. data generally, and to the relatively high rates of the combined regression, as influenced by ISJ data. These comparisons show that novel FR data only sometimes compare very well with the combined Aurelia spp. calculated FR, and that net mesh-size affects the FR estimates.

\section{Other scyphomedusae}

Feeding rates of Chrysaora quinquecirrha and Cyanea capillata medusae were also variable, but very similar to FR of Aurelia spp. (Fig. 2). Data for $C$. quinquecirrha medusae overlapped the Aurelia spp. data by WW, although FR of $C$. capillata medusae were somewhat lower than Aurelia spp. at the same sizes (Fig. 2), possibly because prey are digested more rapidly by $C$. capillata. Data for ISJ A. aurita noticeably differed from the others due to high FR on small Oithona spp. vs. PD; prey available and eaten in PWS and CB were mostly calanoids. As for Aurelia spp., the variables (T, WW, PD, and FR) were all correlated, except that FR of $C$. quinquecirrha was not correlated with $\mathrm{T}$ (Table 1). Therefore, $\mathrm{T}$ was removed from the predictive equation (Table 2), which reduced the $R^{2}(0.455-$ 0.419) and prediction (PRESS values 50.4-53.3) to some extent. WW was more important in determining FR than PD for $C$. quinquecirrha but similar for FR of $C$. capillata.

When Chrysaora quinquecirrha and Cyanea capillata FR data were combined with the Aurelia spp. data, the variables were all correlated, except that FR of scyphomedusae combined was not correlated with PD (Table 1). The overall fit of the scyphomedusa FR regression was reduced $\left(R^{2}=0.672\right)$, although the overall regression and all variables were highly significant $(P<0.001$; Table 2$)$. Removal of T from the predictive regression eliminated multicollinearity and a failed constant variance assumption.
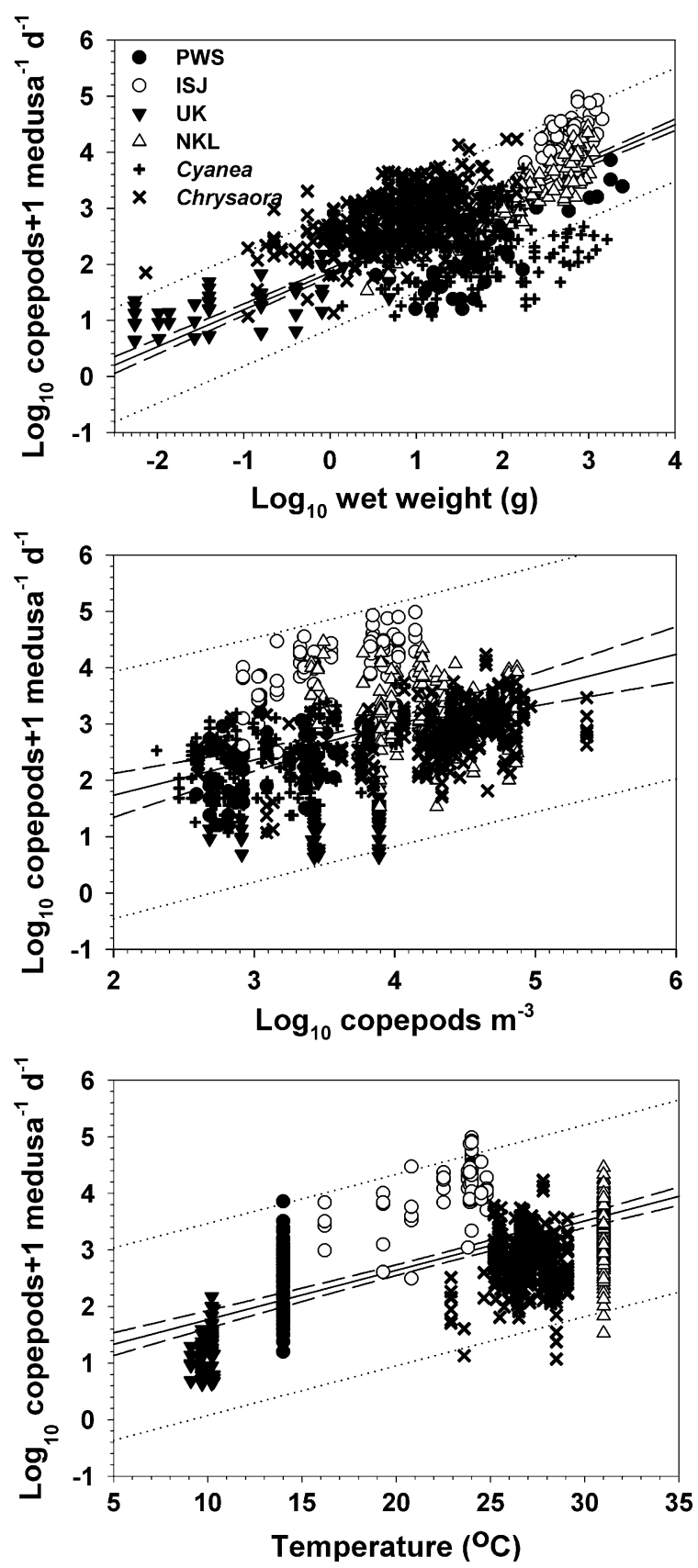

Fig. 2 Feeding rates $\left(\log _{10}\right.$ number of copepods +1 eaten $\left.d^{-1}\right)$ by individual scyphomedusae vs. medusa wet weight (top), prey density (middle), and temperature (bottom) as in Fig. 1 for Aurelia spp., with the addition of Chrysaora quinquecirrha from Chesapeake Bay (Purcell, 1992) and Cyanea capillata from Prince William Sound, Alaska (Purcell, 2003). Location abbreviations for Aurelia spp. and lines are as in Fig. 1

In order to test FR predicted by the species regressions and the combined scyphomedusa regression against the measured FR data, I entered WW and 
Table 4 Conditions of experiments to measure digestion rates of scyphomedusae feeding on copepods

\begin{tabular}{|c|c|c|c|c|c|c|c|}
\hline Medusa species & $\begin{array}{l}\text { Diameter } \\
(\mathrm{mm})\end{array}$ & WW (g) & Copepod species & $\begin{array}{l}\text { Size } \\
(\mathrm{mm})\end{array}$ & $\mathrm{T}\left({ }^{\circ} \mathrm{C}\right)$ & $\begin{array}{l}\text { Digestion } \\
\text { time }(\mathrm{h})\end{array}$ & Reference \\
\hline Aurelia aurita & 39 & 3.7 & $\begin{array}{l}\text { Calanus finmarchicus } \\
\text { (Gunner) }\end{array}$ & 2 & 10 & $2.14-2.51$ & $\begin{array}{l}\text { Båmstedt \& Martinussen } \\
\text { (2001) }\end{array}$ \\
\hline A. aurita & $11-14$ & $0.1-0.2$ & C. finmarchicus & 2 & 10 & $5.4-7.7$ & $\begin{array}{l}\text { Martinussen \& Båmstedt } \\
\text { (2001) }\end{array}$ \\
\hline A. aurita & $13-15$ & $0.15-0.23$ & Pseudocalanus sp. & $0.76-1$ & $9.5-10$ & $3.21-6.26$ & $\begin{array}{l}\text { Martinussen \& Båmstedt } \\
\quad(1999,2001)\end{array}$ \\
\hline A. aurita & 5 & 0.01 & Pseudocalanus sp. & 0.76 & 4.5 & 3.63 & $\begin{array}{l}\text { Martinussen \& Båmstedt } \\
\text { (2001) }\end{array}$ \\
\hline A. aurita & 100 & 54.2 & Acartia omorii Bradford & 0.5 & 19 & 1 & Uye \& Shimauchi (2005) \\
\hline A. aurita & 100 & 54.2 & $\begin{array}{l}\text { Oithona davisae Ferrari } \\
\text { and Orsi }\end{array}$ & 0.5 & 19 & 1 & Uye \& Shimauchi (2005) \\
\hline A. aurita & 60 & 12.6 & Acrocalanus sp. & 0.5 & 30 & 0.71 & Dawson \& Martin (2001) \\
\hline A. aurita & 50 & 7.5 & Mixed & 0.5 & 22.5 & 1.6 & Lo \& Chen (2008) \\
\hline A. aurita & 160 & 207.8 & Mixed & 0.5 & 22.5 & 2.05 & Lo \& Chen (2008) \\
\hline A. aurita & 30 & 1.7 & Calanoids & 0.75 & 7 & 3.5 & Sullivan et al. (1994) \\
\hline A. aurita & 80 & 28.6 & Calanoids & 0.5 & 4 & 3.85 & $\begin{array}{l}\text { Matsakis \& Conover } \\
\text { (1991) }\end{array}$ \\
\hline A. aurita & 166 & 230.9 & Oithona sp. & 0.5 & 22 & 0.95 & Ishii \& Tanaka (2001) \\
\hline A. labiata & 110.6 & 72.3 & Calanoids & 1 & 14 & 3 & Purcell (2003) \\
\hline Cyanea capillata & $65.5-71.5$ & $38.6-49.3$ & C. finmarchicus & 1.5 & 9.5 & $1.5-2.0$ & $\begin{array}{l}\text { Martinussen \& Båmstedt } \\
\text { (1999) }\end{array}$ \\
\hline C. capillata & 102.6 & 135.6 & Calanoids & 1 & 14 & 2 & Purcell (2003) \\
\hline $\begin{array}{l}\text { Chrysaora } \\
\text { quinquecirrha }\end{array}$ & $25-126$ & $1.1-170.4$ & Acartia tonsa Dana & 1 & $20-27$ & $2.5-4.7$ & $\begin{array}{l}\text { Purcell (1992); } \\
\quad \mathrm{Y}=10.86-0.31 \mathrm{~T}\end{array}$ \\
\hline
\end{tabular}

Data were used in regression analyses (Fig. 3). WW, wet weight; T, temperature

PD from each dataset into their own (local) and the combined regressions (Table 3). The combined Aurelia spp. data in the combined scyphomedusa regression gave mean FR of 2,061.1 \pm 133.3 copepods medusa ${ }^{-1} \mathrm{~d}^{-1}$, as compared with the measured FR of $5,899.6 \pm 661.8$ copepods medusa ${ }^{-1} \mathrm{~d}^{-1}$; thus, the scyphomedusa regression underestimated feeding by Aurelia spp. by $180 \%$. Measured Chrysaora quinquecirrha and Cyanea capillata data in local regressions underestimated feeding by 46 and $80 \%$, respectively. The combined regression overestimated measured FR for $C$. quinquecirrha medusae by $50 \%$ and underestimated measured FR for $C$. capillata medusae by $25 \%$. I also tested novel measured FR data for Chrysaora fuscescens Brandt against FR calculated from the $C$. quinquecirrha regression and the combined scyphomedusa regression (Table 3). Both regressions predicted FR of $C$. fuscescens poorly, overestimating measured FR by nearly sixfold.

\section{Digestion times}

In order to calculate feeding rates from gut contents, digestion times (DT) need to be measured. Rates for Aurelia spp. have been measured repeatedly (reviewed in Martinussen \& Båmstedt, 2001; Hansson et al., 2005). I developed a multiple regression equation for Aurelia spp. using DT data measured at ambient temperatures (Table 4). I did not use DT measured at experimentally altered temperatures (Martinussen \& Båmstedt, 2001), which may affect the rates. I did not consider the possible effects of prey number and size, which affect DT of small $A$. aurita (Martinussen \& Båmstedt, 1999).

DT of Aurelia spp. were negatively and significantly correlated with both T and WW (Table 1, Fig. 3). WW were positively correlated with $\mathrm{T}$, which must be due to an experimental artifact; the smallest medusae and no large medusae were tested at cold temperatures (Tables 1, 4). Multiple linear regression 

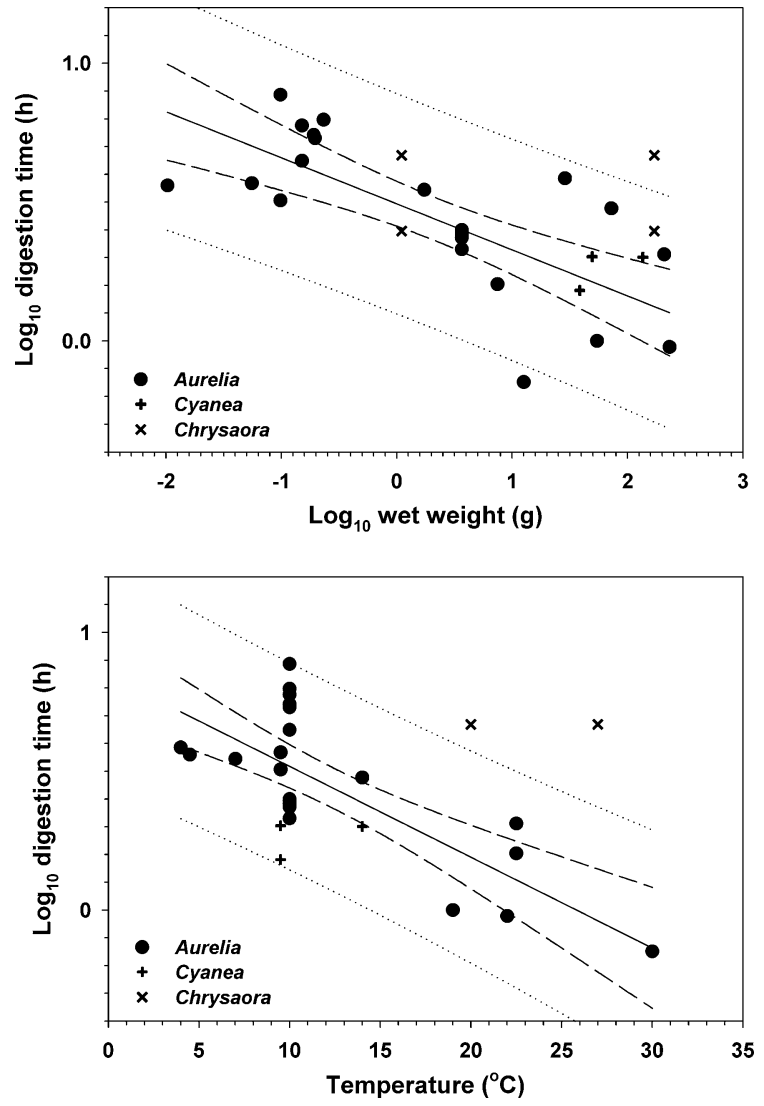

Fig. 3 Digestion times $\left(\log _{10} h\right)$ for scyphomedusae eating copepods vs. medusa wet weight (top) and temperature (bottom) for Aurelia spp. Points for Chrysaora quinquecirrha and Cyanea capillata are shown for comparison but are not included in the regression. Data and sources are in Table 4. Lines are as in Fig. 1

of $\log _{10}$-transformed data passed assumptions of the analysis and showed no multicollinearity. DT were significantly and negatively related to temperature and jellyfish size $\left(F_{2}, \quad 21=23.272 ; \quad P<0.001\right.$; $R^{2}=0.689$ ) (Fig. 3). There was a significant effect of temperature (T; $t=-3.305 ; P=0.003$ ), with digestion by jellyfish of similar size (12.6-28.6 g $\mathrm{WW}$ ) ranging between $0.71 \mathrm{~h}$ at $30^{\circ} \mathrm{C}$ and $3.85 \mathrm{~h}$ at $4^{\circ} \mathrm{C}$. This is equivalent to a $\mathrm{Q}_{10}$ of 2.08. Rapid digestion at warm temperatures may have been exacerbated by small prey sizes at those locations (Dawson \& Martin, 2001; Ishii \& Tanaka, 2001; Uye \& Shimauchi, 2005; Lo \& Chen, 2008). Jellyfish size also was significant (WW; $t=-2.680 ; P=0.014$ ); digestion of copepods by jellyfish $<0.3 \mathrm{~g}$ WW $(<15 \mathrm{~mm}$ diameter $)$ required very long times $(5-8 \mathrm{~h})$ relative to larger jellyfish. Digestion times
(DT in h) for Aurelia spp. jellyfish could be predicted according to the following equation: $\log _{10}$ $\mathrm{DT}=0.745-\left(0.0943 * \log _{10} \mathrm{WW}\right)-(0.0211 * \mathrm{~T})$.

DT for Cyanea capillata and Chrysaora quinquecirrha were similar to those for Aurelia spp. medusae of similar sizes (Fig. 3), although DT for C. capillata were shorter, and DT for C. quinquecirrha were longer than those for Aurelia spp. medusae at similar temperatures (Fig. 3).

\section{Ctenophores}

Most studies of feeding rates of Mnemiopsis leidyi (called M. mccradyi in some publications) ctenophores have been in experimental containers from 4 to 1,000 1 volume (reviewed in Purcell et al., 2001b; see also Kremer \& Reeve, 1989; Decker et al., 2004; Purcell \& Decker, 2005). Clearance rates (CR in liters cleared of prey ctenophore ${ }^{-1} \mathrm{~d}^{-1}$ ) usually are presented relative to ctenophore size (Table 5). I reanalyzed raw data for ctenophores (mostly lobates $>1 \mathrm{~cm}$ ) feeding on copepods from earlier publications (Kremer \& Reeve, 1989; Purcell et al., 2001b; Decker et al., 2004). I did not include data for cydippid larvae feeding on nauplii and microplankton (Stoecker et al., 1987a; Sullivan \& Gifford, 2004; Finenko et al., 2006). I only used data measured at ambient temperatures because adjustment to new temperatures might affect feeding. CR measured in small containers seem low relative to those measured in large containers, and probably are not representative of in situ rates (Purcell et al., 2001b). This has not been tested directly, and probably depends on ctenophore size. Therefore, I tested M. leidyi CR measured in 3.5-1,000-1 containers vs. ctenophore size, prey density, and temperature with Pearson product moment correlations and regressions (Tables 3, 5, 6, Figs. 4, 5).

$\mathrm{CR}$ on copepods were strongly correlated with ctenophore size (WW) in the three studies separately and combined (Table 5, Fig. 4). Prey densities (PD) were not significantly correlated with $\mathrm{CR}$ in any study. CR increased with container volume (CV). Experimental conditions were co-correlated in the combined analysis. CV was correlated with WW, because containers (3.5-55 1) were chosen according to ctenophore size and differed between datasets. PD was correlated with $\mathrm{CV}$ and $\mathrm{T}$, because very high (100 and 200 copepods $1^{-1}$ ) prey densities were used 
Table 5 Pearson product moment correlations of Mnemiopsis leidyi ctenophore wet weight (WW in $\mathrm{g}$ ), prey density (PD in copepods $1^{-1}$ ), temperature $\left(\mathrm{T}\right.$ in $\left.{ }^{\circ} \mathrm{C}\right)$, and container volume ( $\mathrm{CV}$ in liters) with the clearance rate (CR in liters cleared ctenophore $^{-1} \mathrm{~d}^{-1}$ )

\begin{tabular}{|c|c|c|}
\hline \multirow[t]{2}{*}{ Pair of variables } & \multicolumn{2}{|c|}{ Pearson's correlation } \\
\hline & $R$ & $P$ \\
\hline $\mathrm{CR}_{90}$ vs. $\mathrm{WW}_{90}$ & 0.579 & $3.42 \times 10^{-10}$ \\
\hline $\mathrm{CR}_{90}$ vs. $\mathrm{PD}_{90}$ & -0.067 & 0.511 \\
\hline $\mathrm{CR}_{90}$ vs. $\mathrm{T}_{90}$ & 0.194 & 0.054 \\
\hline$W_{90}$ vs. PD $_{90}$ & 0.018 & 0.857 \\
\hline $\mathrm{WW}_{90}$ vs. $\mathrm{T}_{90}$ & 0.440 & $5.23 \times 10^{-6}$ \\
\hline$T_{90}$ vs. $P_{90}$ & 0.058 & 0.568 \\
\hline $\mathrm{CR}_{1000}$ vs. WW $\mathrm{WW}_{100}$ & 0.410 & 0.01 \\
\hline $\mathrm{CR}_{1000}$ vs. $\mathrm{PD}_{1000}$ & -0.312 & 0.068 \\
\hline $\mathrm{CR}_{1000}$ vs. $\mathrm{CV}_{1000}$ & -0.0386 & 0.826 \\
\hline $\mathrm{WW}_{1000}$ vs. $\mathrm{CV}_{1000}$ & 0.438 & 0.008 \\
\hline$W_{1000}$ vs. $P_{1000}$ & -0.179 & 0.304 \\
\hline $\mathrm{PD}_{1000}$ vs. $\mathrm{CV}_{1000}$ & -0.351 & 0.038 \\
\hline $\mathrm{CR}_{55}$ vs. $\mathrm{WW}_{55}$ & 0.865 & $8.45 \times 10^{-64}$ \\
\hline $\mathrm{CR}_{55}$ vs. $\mathrm{PD}_{55}$ & 0.122 & 0.080 \\
\hline $\mathrm{CR}_{55}$ vs. $\mathrm{CV}_{55}$ & 0.424 & $1.61 \times 10^{-10}$ \\
\hline $\mathrm{WW}_{55}$ vs. $\mathrm{CV}_{55}$ & 0.217 & 0.002 \\
\hline $\mathrm{WW}_{55}$ vs. $\mathrm{PD}_{55}$ & 0.369 & $3.76 \times 10^{-8}$ \\
\hline $\mathrm{PD}_{55}$ vs. $\mathrm{CV}_{55}$ & -0.051 & 0.461 \\
\hline $\mathrm{CR}_{\mathrm{MN}}$ vs. $\mathrm{WW}_{\mathrm{MN}}$ & 0.565 & $2.91 \times 10^{-30}$ \\
\hline $\mathrm{CR}_{\mathrm{MN}}$ vs. $\mathrm{PD}_{\mathrm{MN}}$ & -0.166 & 0.002 \\
\hline $\mathrm{CR}_{\mathrm{MN}}$ vs. $\mathrm{CV}_{\mathrm{MN}}$ & 0.459 & $2.70 \times 10^{-19}$ \\
\hline $\mathrm{CR}_{\mathrm{MN}}$ vs. $\mathrm{T}_{\mathrm{MN}}$ & 0.601 & $4.84 \times 10^{-35}$ \\
\hline $\mathrm{WW}_{\mathrm{MN}}$ vs. $\mathrm{CV}_{\mathrm{MN}}$ & 0.139 & 0.010 \\
\hline $\mathrm{WW}_{\mathrm{MN}}$ vs. $\mathbf{P D}_{\mathrm{MN}}$ & -0.053 & 0.331 \\
\hline $\mathrm{T}_{\mathrm{MN}}$ vs. $\mathrm{WW}_{\mathrm{MN}}$ & 0.378 & $4.54 \times 10^{-13}$ \\
\hline $\mathrm{PD}_{\mathrm{MN}}$ vs. $\mathrm{CV}_{\mathrm{MN}}$ & -0.245 & $3.33 \times 10^{-6}$ \\
\hline $\mathrm{T}_{\mathrm{MN}}$ vs. $\mathrm{PD}_{\mathrm{MN}}$ & -0.363 & $3.94 \times 10^{-12}$ \\
\hline $\mathrm{T}_{\mathrm{MN}}$ vs. $\mathrm{CV}_{\mathrm{MN}}$ & -0.0231 & 0.775 \\
\hline
\end{tabular}

$R$, correlation coefficient; $P$, probability; $P>0.05$ are not significant (marked in bold). Data are from 90-1 containers (90; Decker et al., 2004), 1,000-1 mesocosms (1,000; Purcell, unpublished), $\leq 55-1$ containers (55; Kremer \& Reeve, 1989). MN, combined Mnemiopsis

only in 3.5-55-1 containers, while PD were lowest and $\mathrm{T}$ highest in 1,000-1 containers. For subsequent regression analyses, I removed $\mathrm{PD}$ (not significant) and $\mathrm{T}$, which was over a small range $\left(21-25^{\circ} \mathrm{C}\right)$ and was correlated with other experimental conditions.
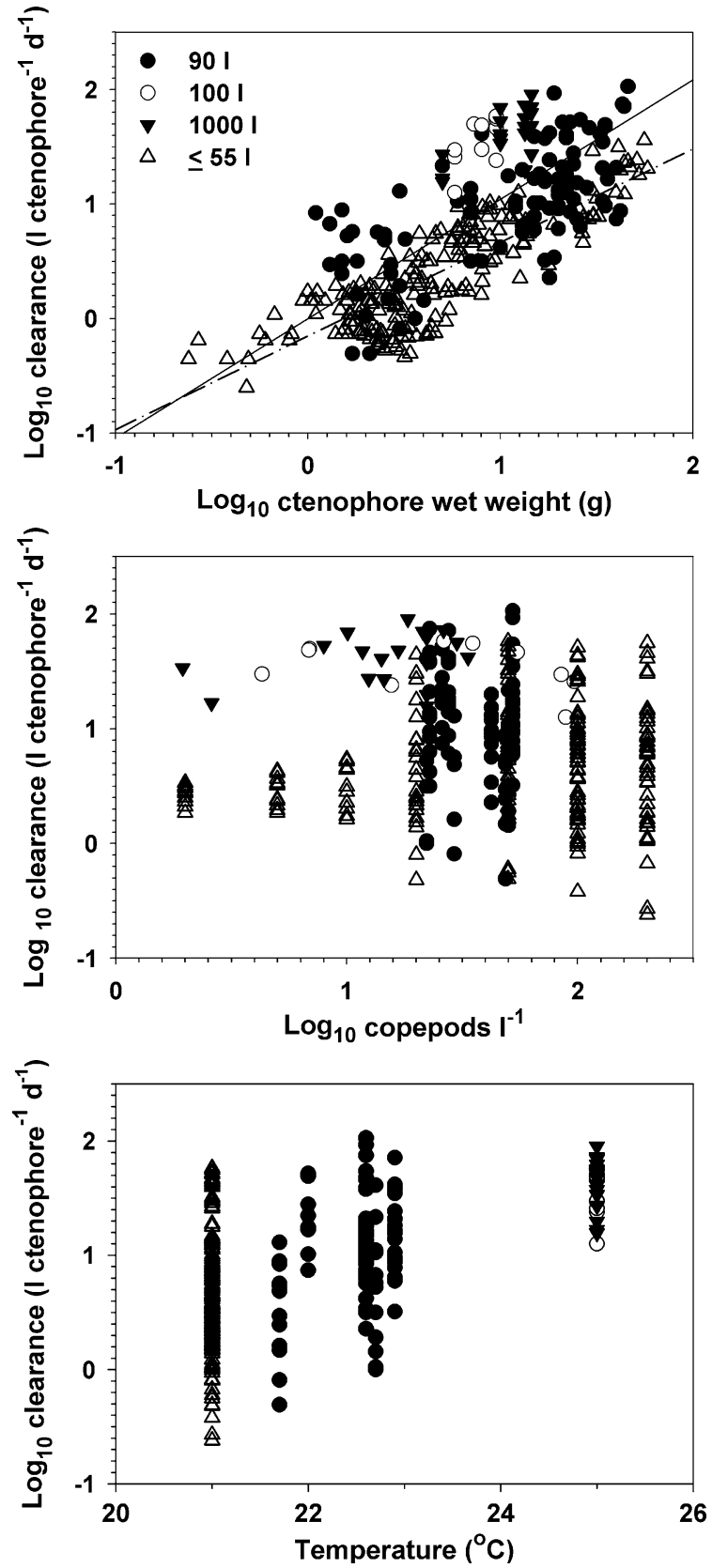

Fig. 4 Clearance rates $\left(\log _{10}\right.$ liters cleared ctenophore $\left.{ }^{-1} \mathrm{~d}^{-1}\right)$ for Mnemiopsis leidyi feeding on copepods vs. wet weight (top), prey density (middle), and temperature (bottom). Laboratory experiments were conducted in containers of 90-1 (Decker et al., 2004), 100- and 1,000-1 (Purcell, unpublished), and 3.555-1 (Kremer \& Reeve, 1989). Regression lines shown vs. wet weight are dot-dash for $\leq 55-1$ and solid for others combined

Because of the strong correlations between CR and $\mathrm{CV}$, additional analyses were made for Mnemiopsis leidyi. Toonen \& Chia (1993) recommended a ratio of 
Table 6 Clearance rates ( $\mathrm{CR}$ in liters cleared ctenophore ${ }^{-1} \mathrm{~d}^{-1}$ ) of Mnemiopsis leidyi in relation to container size

\begin{tabular}{|c|c|c|c|c|c|c|c|c|}
\hline \multirow[t]{3}{*}{ Ctenophore size (mm) } & \multicolumn{6}{|c|}{ Mean or median clearance rate (number) } & \multirow[t]{3}{*}{$\mathrm{F}$ or $\mathrm{H}$ statistic } & \multirow[t]{3}{*}{$P$} \\
\hline & \multicolumn{6}{|c|}{ Container volume (1) } & & \\
\hline & 3.5 & 20 & 40 & 55 & 90 & 1,000 & & \\
\hline $10-14$ & - & 1.85 (37) $a$ & $4.21(12) b$ & - & $6.70(3) b$ & - & $H_{2}=27.729$ & $<0.001$ \\
\hline $15-20$ & $1.60(10) a$ & - & - & $3.70(25) b$ & $3.15(25) b$ & - & $H_{2}=9.861$ & 0.007 \\
\hline $20-30$ & $6.50(12)$ & $3.64(5) a$ & $5.58(3)$ & $9.36(13) b$ & $4.86(9)$ & $16.74(3) b$ & $H_{5}=16.221$ & 0.006 \\
\hline $30-40$ & 8.20 (19) $a$ & $9.15(6) a$ & - & 24.15 (9) $b$ & $8.32(6) a$ & - & $F_{3,36}=22.440$ & $<0.001$ \\
\hline $40-50$ & $8.43(9) a$ & - & - & $30.80(6) b$ & $8.16(8) a$ & 41.77 (9) $b$ & $H_{3}=23.000$ & $<0.001$ \\
\hline
\end{tabular}

Statistical tests were one way ANOVA (F statistic) or Kruskal-Wallis one way ANOVA on Ranks (H statistic) by ctenophore size. Numbers of replicates are in parentheses. Different letters $(a, b)$ indicate significantly different groups determined by multiple comparison procedures (Dunn's Method). $P$, probability; $P>0.05$ are not significant

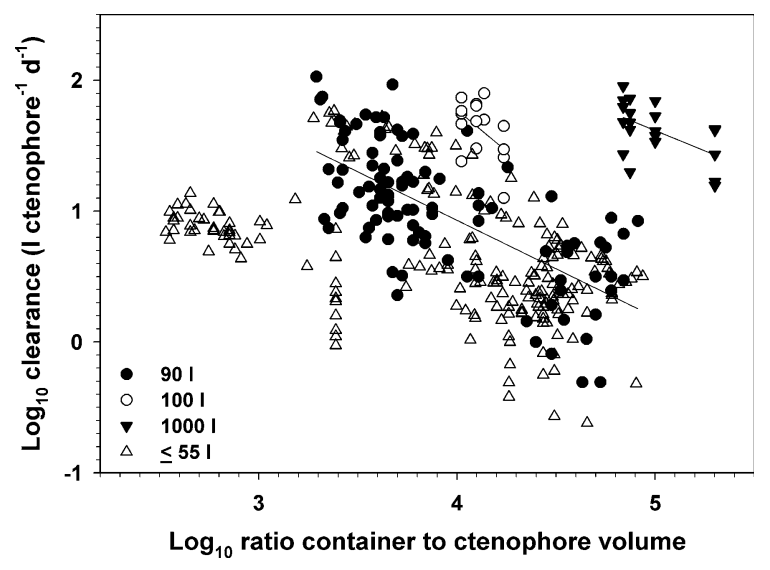

Fig. 5 Effect of container size (3.5-1,000 1) on clearance rates $\left(\log _{10} 1\right.$ cleared ctenophore $\left.{ }^{-1} \mathrm{~d}^{-1}\right)$ for Mnemiopsis leidyi feeding on copepods in laboratory experiments (as in Fig. 4). Clearance rates are plotted against the $\log _{10}$ ratios of container volume to ctenophore volume. The regression line for containers $\leq 551$ is omitted for clarity

container volume to jellyfish volume of $\geq 15,000: 1$ for the small, ambush predator, Proboscidactyla flavicirrata (Brandt), otherwise, feeding by the hydromedusan was affected. Comparison of the ratios of $\mathrm{CV}$ to ctenophore volume $(\sim \mathrm{WW})$ showed that when ratios were $<2,500: 1, \mathrm{CR}$ were reduced (Fig. 5). CR of ctenophores of similar size in containers of different sizes $(3.5-1,0001)$ were greater in the larger containers $(P \leq 0.006)$, and greatest in 1,000-1 (Table 6). Therefore, for subsequent regression analyses of $\mathrm{CR}$, I removed data from 3.5- and 4-1 containers, which all had low volume ratios. The remaining data had volume ratios of 2,500 to 200,000. I also removed data from experiments using 200 prey $^{-1}$ (from Kremer \& Reeve, 1989), which was a much higher PD than that used in the other studies.

The individual and combined regressions of WW on CR were strong (Table 7). Thus, clearance rates of Mnemiopsis leidyi feeding on copepods in situ can be estimated from data on ctenophore size. The reliability of predicting CR is of great importance; therefore, to test predictions of the regressions vs. the measured CR, I entered WW from each dataset into their own (local) and the combined regression (Table 3). Measured M. leidyi CR matched CR from the 20-55-1 regression $(+2 \%)$ and underestimated $\mathrm{CR}$ in 90 - and 1,000-1 regressions by $10-22 \%$. The combined $M$. leidyi $\mathrm{CR}$ regression underestimated measured $\mathrm{CR}$ in $20-55-1$ by $16 \%$ and CR in $1,000-1$ by $159 \%$; CR in 90-1 containers were overestimated by $10 \%$. The PRESS statistics indicated that all local regressions would be good predictors of feeding, while the combined equation (PRESS $=28.8$ ) was a relatively worse predictor.

\section{Use of metabolic rates to estimate jellyfish and ctenophore predation on large scales}

Respiration and excretion are basic physiological processes that are related to body mass, temperature, and activity for all animals. They have been used to estimate the minimum food requirements and ingestion for some gelatinous species (e.g., Ishii \& Tanaka, 2006). Although metabolic rates yield low feeding estimates because they usually are measured on unfed animals and also lack estimates for growth (but see 
Table 7 Clearance rate (CR; liters cleared ctenophore ${ }^{-1} \mathrm{~d}^{-1}$ ) equations for Mnemiopsis leidyi ctenophores calculated from regression analysis (last equation, combined)

\begin{tabular}{|c|c|c|c|c|c|c|}
\hline \multirow{2}{*}{$\begin{array}{l}\text { Container } \\
\text { volume (l) } \\
\text { (number } \\
\text { examined) }\end{array}$} & \multicolumn{2}{|c|}{ Wet weight (WW in $\mathrm{g}$ ) } & \multirow{2}{*}{$\begin{array}{l}\mathrm{CR} \\
\text { Range }\end{array}$} & \multirow[t]{2}{*}{$R^{2}$ and $F$} & \multirow[t]{2}{*}{$P$ and SE } & \multirow[t]{2}{*}{ Predictive equation } \\
\hline & Range & $t$ and $P$ & & & & \\
\hline $20-55(126)$ & $0.25-24.2$ & $\begin{array}{l}t=19.876 \\
P<0.001\end{array}$ & $0.4-58.1$ & $\begin{array}{l}R^{2}=0.761 \\
F_{1,124}=395.054\end{array}$ & $\begin{array}{l}P<0.001 \\
\text { SE } 0.232\end{array}$ & $\log _{10} C R=0.945 * \log _{10} W W+0.416$ \\
\hline $1,000(16)$ & $5.0-14.5$ & $\begin{array}{l}t=2.918 \\
P=0.003\end{array}$ & $15.6-72.3$ & $\begin{array}{l}R^{2}=0.476 \\
F_{1,14}=12.722\end{array}$ & $\begin{array}{l}P=0.003 \\
\text { SE } 0.158\end{array}$ & $\log _{10} \mathrm{CR}=0.843 * \log _{10} \mathrm{WW}+0.715$ \\
\hline $90(78)$ & $1.1-44.0$ & $\begin{array}{l}t=4.839 \\
P<0.001\end{array}$ & $1.0-74.6$ & $\begin{array}{l}R^{2}=0.589 \\
F_{1,88}=108.741\end{array}$ & $\begin{array}{l}P<0.001 \\
\text { SE } 0.275\end{array}$ & $\log _{10} \mathrm{CR}=0.699 * \log _{10} \mathrm{WW}+0.361$ \\
\hline Combined (220) & $0.25-44.0$ & $\begin{array}{l}t=23.496 \\
P<0.001\end{array}$ & $0.4-74.6$ & $\begin{array}{l}R^{2}=0.717 \\
F_{1,247}=552.072\end{array}$ & $\begin{array}{l}P<0.001 \\
\text { SE } 0.281\end{array}$ & $\log _{10} \mathrm{CR}=0.766 * \log _{10} \mathrm{WW}+0.423$ \\
\hline
\end{tabular}

$t, t$ statistic; $P$, probability where $P>0.05$ are not significant; $R^{2}$, coefficient of determination; $F$, F statistic; SE, standard error

Møller \& Riisgård, 2007), they have the advantage of being measured in laboratory containers with fewer artifacts than feeding rates. I hypothesize that respiration rates can be predicted by multiple regressions of predator size and temperature (e.g., Uye \& Shimauchi, 2005; Ishii \& Tanaka, 2006), and thus, feeding can be estimated from metabolic rates across species.

I tested this hypothesis for scyphomedusae by comparing published regressions of respiration rates (RR) measured at ambient temperatures for Aurelia aurita, A. labiata, Chrysaora quinquecirrha (converted from excretion by use of the atomic ratio (11.6:1) of oxygen respired to nitrogen excreted), and Cyanea capillata (Table 8). Medusa mass was standardized to carbon (C) by published conversions (Table 9). I entered RRs at the minimum and maximum sizes at experimental temperatures for each regression (1 point for each temperature and size; Fig. 6) in a multiple regression to predict respiration rate $\left(\mathrm{ml} \mathrm{O}_{2}\right.$ medusa $\left.{ }^{-1} \mathrm{~d}^{-1}\right)$ from medusa mass $(\mathrm{g} \mathrm{C})$ and temperature $\left({ }^{\circ} \mathrm{C}\right)$. The regression for Aurelia spp. was strong $\left(R^{2}=0.954 ; P<0.001\right)$, with mass being significant, but not temperature (Table 10). The regression for scyphomedusan species was equally strong $\left(R^{2}=0.951 ; P<0.001\right)$, with respiration rates of $C$. quinquecirrha and $C$. capillata coinciding with those of Aurelia spp. (Fig. 6); again, mass was significant, but temperature was not (Table 10). The regressions were recalculated without temperature for the predictive equations (Table 10). PRESS statistics indicated strong predictability of the regressions (Aurelia spp. 1.206; scyphomedusae 1.432). Respiration rates of Aurelia spp. medusae of equal mass were similar across ambient temperatures from 10 to $30^{\circ} \mathrm{C}$, in marked contrast to published increases determined in the laboratory (e.g., $\mathrm{Q}_{10}=2.9$; Fig. 7); $\mathrm{Q}_{10}$ of the combined Aurelia spp. regression was only 1.67. Respiration of C. quinquecirrha increased somewhat with temperature. It was unclear if temperature in the C. capillata experiment was adjusted to $15^{\circ} \mathrm{C}$ (Larson, 1987).

I also developed a multiple regression equation for respiration rate vs. mass and temperature for Mnemiopsis leidyi ctenophores (2 sizes) from published respiration equations at ambient temperatures (Table 8). I did not include the regression from Pavlova \& Minkina (1993), which gave very low rates compared with the others. I used data only from freshly collected ctenophores from Kremer (1982). The combined regression for $M$. leidyi was strong $\left(R^{2}=0.874 ; P<0.001\right)$, with mass but not temperature being significant (Table 10, Fig. 6). The regression was recalculated without temperature for the predictive equation (Table 10). The PRESS statistic (2.279) indicated that the regression would be a good predictor of respiration. Respiration rates of M. leidyi ctenophores of equal mass ( $\mathrm{g} \mathrm{C}$ ) showed a greater sensitivity to temperature than scyphomedusae (Fig. 7); however, temperature was not significant in the multiple regression (Table 10). Experimental temperatures in Miller (1970) differed by 0 to $8^{\circ} \mathrm{C}$ from ambient; his data suggest that respiration rates may be reduced when ctenophores 


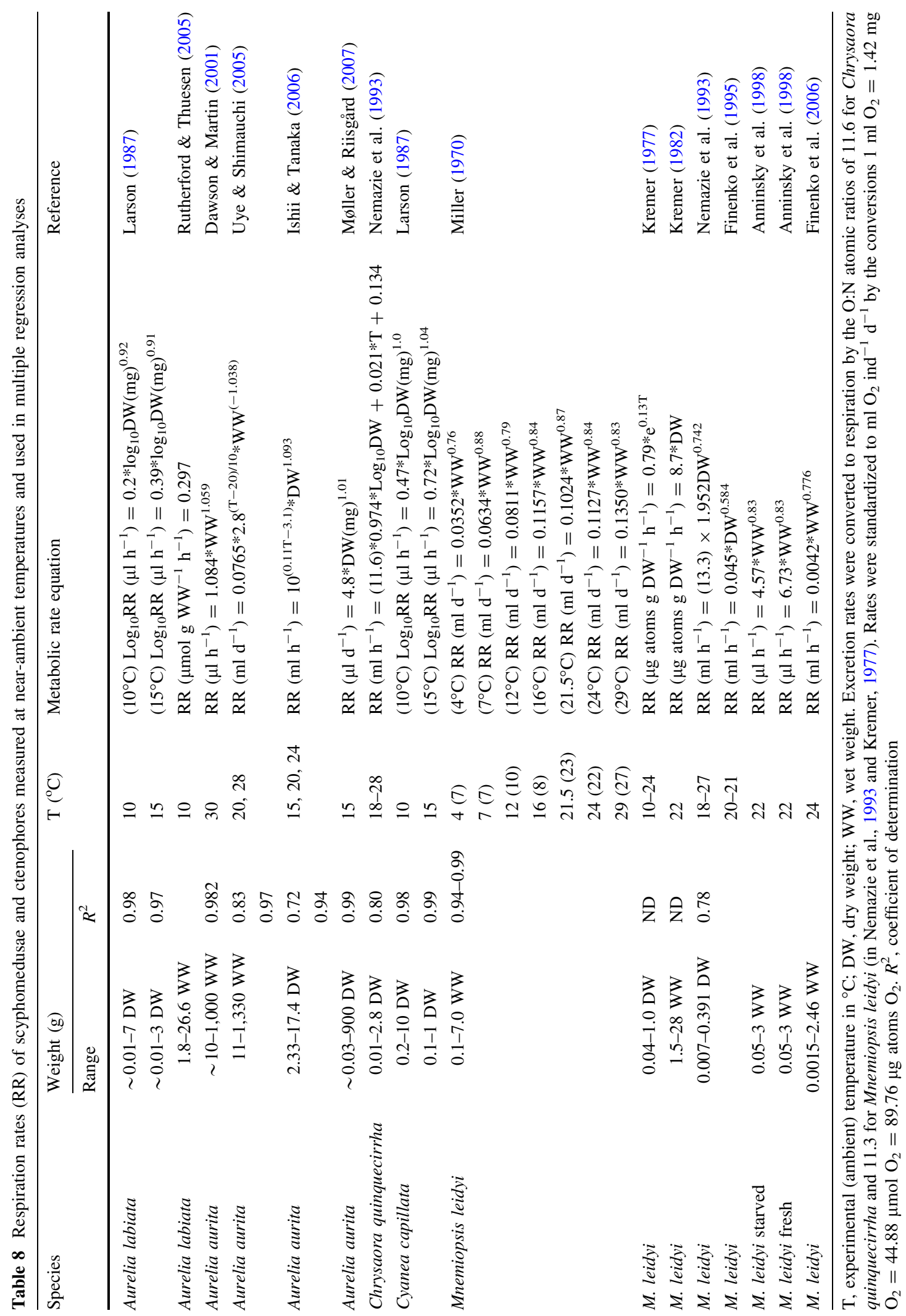


Table 9 Biometric conversions and $\mathrm{Q}_{10}$ s for scyphomedusae and ctenophores, with ambient salinities

\begin{tabular}{lcccll}
\hline Species & $\mathrm{Q}_{10}$ & DW\%WW & C\%DW & Salinity & Reference \\
\hline Aurelia aurita & 2.8 & 3.6 & 3.7 & $>30$ & Uye \& Shimauchi (2005) \\
Aurelia aurita & $\mathrm{ND}$ & $\mathrm{ND}$ & 3.9 & $\mathrm{ND}$ & Ishii \& Tanaka (2006) \\
Aurelia aurita & 3.1 & $\mathrm{ND}$ & 5 & 20.0 & Møller \& Riisgård (2007) \\
Aurelia labiata & 2.9 & 3.8 & 4 & $28-30$ & Larson (1986) \\
Cyanea capillata & 3.4 & 4.2 & 13 & $28-30$ & Larson (1986) \\
Chrysaora quinquecirrha & 1.6 & 0.95 & 11.1 & $6-12$ & Nemazie et al. (1993) \\
Mnemiopsis leidyi & 3.7 & 3.4 & 1.7 & 31 & Kremer (1977) \\
Mnemiopsis leidyi & 3.4 & $\mathrm{ND}$ & 4.2 & 18 & Finenko et al. (1995) \\
Mnemiopsis leidyi & 3.4 & 0.95 & 5.1 & $6-12$ & Nemazie et al. (1993)
\end{tabular}

DW, dry weight; WW, wet weight; $\mathrm{C}$, carbon. ND, no data

were cooled, and conversely, increased when warmed (Fig. 7, Table 8). $\mathrm{Q}_{10}$ calculated from the M. leidyi combined equation $=1.33$, which is less than the published $\mathrm{Q}_{10} \mathrm{~s}(\geq 3.4$; Table 9).

The respiration rates for medusae and ctenophores can be used to estimate predation rates. The minimum daily carbon ingestion (MDCI) can be calculated by multiplying the daily respiration rate by the respiratory quotient $(\mathrm{RQ}=0.8)$. The MDCI can be converted to numbers of prey ingested from prey carbon mass when the prey types are known (e.g., ICES, 2000). Estimates of predation effects on prey populations can be made from these data and in situ prey densities. Thus, estimates of predation by gelatinous species in situ can be made from laboratory respiration or excretion measurements, in combination with field data on predator mass and density, prey type, densities, and temperature.

\section{Discussion}

General comments and suggestions

Any estimation of the importance of jellyfish relies first on the determination of their abundance and biomass. Generally, sampling effort is limited by logistics, and the method chosen is assumed to be adequate. Very few studies evaluate the efficacy of any method of estimating jellyfish abundance. Aurelia aurita densities in aggregations determined by echo sounder were much lower than those in net $(0.8-$ $1.6 \mathrm{~m}$ mouth) tows (Toyokawa et al., 1997). Towedcamera estimates of $A$. aurita abundance compared very well against Tucker trawl estimates (Graham
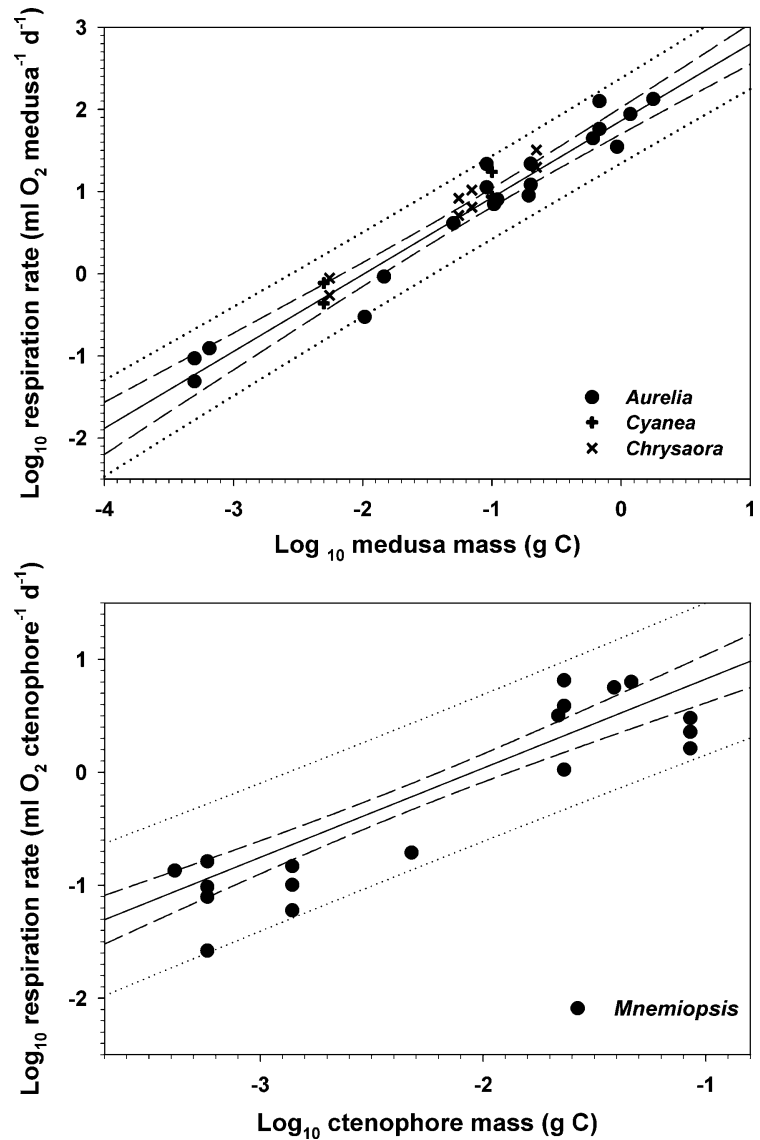

Fig. 6 Respiration rates measured at ambient temperatures from published regressions (Table 8) against mass. Top for scyphomedusae Aurelia spp., Cyanea capillata, and Chrysaora quinquecirrha. Bottom for Mnemiopsis leidyi ctenophores. Lines are as in Fig. 1

et al., 2003a, b). Densities of robust medusae (Periphylla periphylla) sampled by several nets and trawls, an ROV, and acoustics were compared by 
Table 10 Regression analyses evaluating the relationships of jellyfish (Aurelia spp., Cyanea capillata, and Chrysaora quinquecirrha) or ctenophore (Mnemiopsis leidyi) mass (in g carbon, C) and ambient temperature (T) with respiration rates (RR)

\begin{tabular}{|c|c|c|c|c|c|c|c|c|}
\hline \multirow[t]{2}{*}{ Predator } & \multirow[t]{2}{*}{$n$} & \multicolumn{2}{|c|}{ Weight (g carbon) } & \multicolumn{2}{|c|}{ Temperature $\left({ }^{\circ} \mathrm{C}\right)$} & \multirow{2}{*}{$\begin{array}{l}R^{2} \text { and } F \\
\text { statistics }\end{array}$} & \multirow{2}{*}{$\begin{array}{l}P \text { and SE } \\
\text { overall }\end{array}$} & \multirow[t]{2}{*}{ Predictive equation } \\
\hline & & Range & $t$ and $P$ & Tested & $t$ and $P$ & & & \\
\hline $\begin{array}{l}\text { Aurelia spp. } \\
\text { combined }\end{array}$ & 19 & $0.0005-1$ & $\begin{array}{l}t=12.270 \\
P<0.001\end{array}$ & $10-30$ & $\begin{array}{l}t=-0.608 \\
P=0.552\end{array}$ & $\begin{array}{l}0.954 \\
F_{1,17}=345.74\end{array}$ & $\begin{array}{l}P<0.001 \\
\text { SE } 0.245\end{array}$ & $\begin{array}{l}\log _{10} \mathrm{RR}\left(\mathrm{ml} \mathrm{O}_{2} \mathrm{~d}^{-1}\right)=0.936^{*} \\
\quad \log _{10} \mathrm{C}+1.862\end{array}$ \\
\hline $\begin{array}{l}\text { Scyphomedusae } \\
\text { combined }\end{array}$ & 31 & $0.0005-1.7$ & $\begin{array}{l}t=22.268 \\
P<0.001\end{array}$ & $10-30$ & $\begin{array}{l}t=0.338 \\
P=0.738\end{array}$ & $\begin{array}{l}0.951 \\
F_{1,29}=563.80\end{array}$ & $\begin{array}{l}P<0.001 \\
\text { SE } 0.212\end{array}$ & $\begin{array}{l}\log _{10} \mathrm{RR}\left(\mathrm{ml} \mathrm{O}_{2} \mathrm{~d}^{-1}\right)=0.935^{*} \\
\quad \log _{10} \mathrm{C}+1.907\end{array}$ \\
\hline $\begin{array}{l}\text { Mnemiopsis } \\
\quad \text { leidyi } \\
\text { combined }\end{array}$ & 18 & $0.0014-0.02$ & $\begin{array}{l}t=9.935 \\
P<0.001\end{array}$ & $4-29$ & $\begin{array}{l}t=0.998 \\
P=0.334\end{array}$ & $\begin{array}{l}0.874 \\
F_{1,16}=102.879\end{array}$ & $\begin{array}{l}P<0.001 \\
\text { SE } 0.308\end{array}$ & $\begin{array}{l}\log _{10} \mathrm{RR}\left(\mathrm{ml} \mathrm{O}_{2} \mathrm{~d}^{-1}\right)=0.871^{*} \\
\quad \log _{10} \mathrm{C}+1.686\end{array}$ \\
\hline
\end{tabular}

$t, t$ statistic; $P$, probability where $P>0.05$ are not significant; $R^{2}$, coefficient of determination; $F$, F statistic; SE, standard error. Data from regressions in Table 8
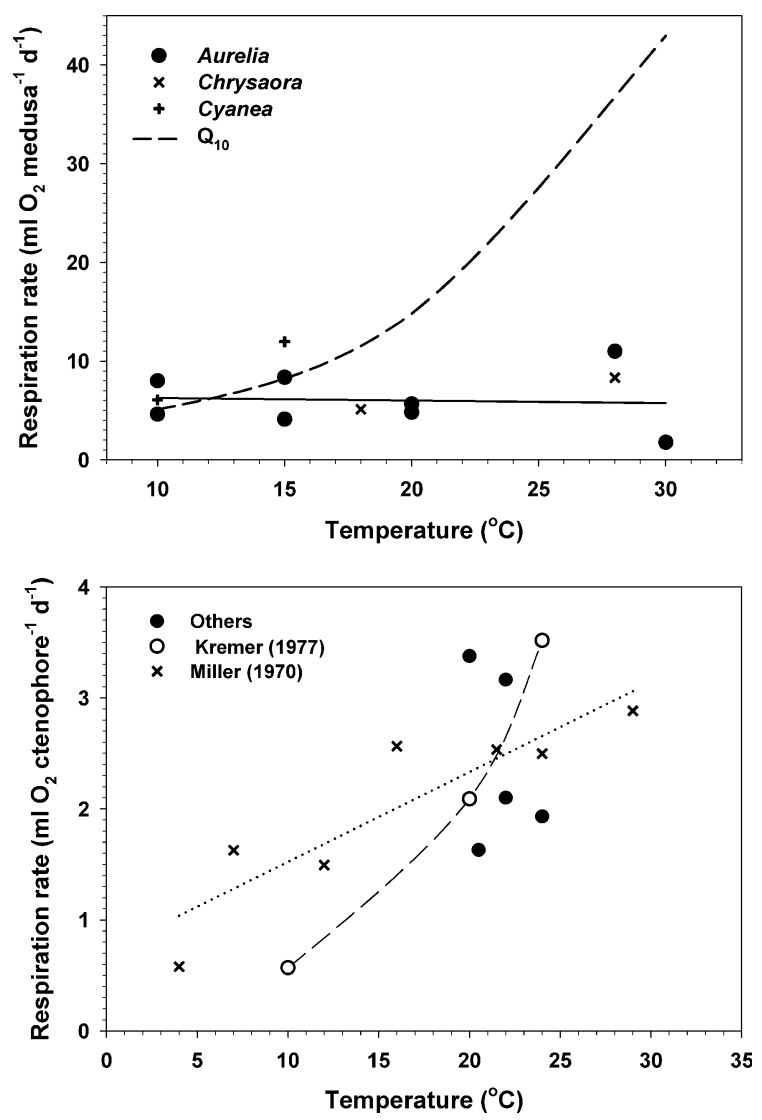

Fig. 7 Respiration rates against ambient/experiment temperatures from regressions in Table 8. Top for scyphomedusae (Aurelia spp., Cyanea capillata, and Chrysaora quinquecirrha) of equal sizes $(0.6-0.7 \mathrm{~g} \mathrm{C})$. The dashed line shows predicted respiration for Aurelia spp. assuming a $\mathrm{Q}_{10}$ of 2.9 (Larson, 1987). Solid line is for all data points. Bottom for Mnemiopsis leidyi ctenophores of equal sizes $(\sim 0.02 \mathrm{~g} \mathrm{C})$. Dashed line is for Kremer (1977) and dotted line is linear regression for Miller (1970)
Båmstedt et al. (2003). Evaluation of all of the reviewed methods is important for meaningful estimates of jellyfish ecosystem effects. If a semiquantitative method is employed (e.g., surface surveys), efforts should be made to determine what portion of the population is being sampled, and ideally, develop an index to convert the method to abundance/biomass estimates.

Sizes of gelatinous species and conversions among mass units (WW, DW, C) have been determined repeatedly (see Larson, 1986; ICES, 2000). The relationships are very consistent (Table 9), and probably do not need to be measured in every location. One difficulty in mass conversions is that DW increases with salinity, and hence, conversions involving DW and dried tissues (e.g., C) differ depending on ambient salinity, as emphasized by Nemazie et al. (1993) and Hirst \& Lucas (1998). Thus, use of DW should be avoided, and necessary conversions from DW should be from specimens from similar ambient salinities.

For gelatinous zooplankton to be included in ecosystem models, data on diet and trophic level, population and individual biomass, as well as growth (production) need to be collected (see Pauly et al., 2008). Dietary data already have been published for many common species. Stable isotopes can yield new insights into trophic interactions. Population biomass and growth data generally have been incompletely collected on depth, spatial, and temporal scales. More in situ data are needed on the polyp, ephyra, and planula stages, specifically, when and where do the various stages occur, and the dates of strobilation in relation to environmental variables. Depth-specific 
data are important. Greater emphasis on such data would greatly improve our understanding of gelatinous species in the ocean's ecosystems.

In this review, I focused on scyphomedusae for several reasons. First, large-scale sampling techniques work best or only for large species. Second, reports of problem blooms of scyphomedusae have increased in recent decades. Third, abundant data are available for temperate semaeostome scyphomedusae, especially Aurelia spp. Semaeostomes are the predominant scyphomedusae in cool coastal waters, but rhizostome scyphomedusae can predominate in tropical waters. Comparatively few studies exist on rhizostome ecology (but see Larson, 1991; Graham et al., 2003a; Pitt \& Kingsford, 2003; Pitt et al., 2005, 2007; Uye, 2008; West et al., 2008). Rhizostomes are also of particular interest because of problem blooms (e.g., Graham et al., 2003a; Uye, 2008), and the use of some species as human food (Omori \& Nakano, 2001). Millions of the preferred species, Rhizostoma esculentum Kishinouye, are reared and released in Chinese waters annually for later harvest (Dong et al., 2008) with little understanding of the ecological effect (Liu \& Bi, 2006). Because of their large sizes and complex feeding structures, rhizostome medusae are excellent candidates for estimation of consumption from respiration rates (e.g., Uye, 2008). Rhizostomes are stronger swimmers than semaeostomes (D'Ambra et al., 2001); therefore, their feeding rates and metabolic demands probably are greater and will require analyses separate from the semaeostomes.

Although scyphomedusae form conspicuous blooms and may predominate as predators in summer, the other gelatinous taxa should not be neglected. There are now approximately 840 recognized species of hydromedusae (Bouillon \& Boero, 2000), as compared with only 190 species of scyphomedusae (Arai, 1997), 20 species of cubomedusae (Mianzan \& Cornelius, 1999), 200 species of siphonophores (Pugh, 1999), and 150 species of ctenophores (Mianzan, 1999). Only a small fraction of these many species have been studied. The small hydromedusae and fragile ctenophores, in particular, often go unnoticed; however, they are ubiquitous, can occur in high densities and biomass in coastal waters, are important predators (e.g., Pagès et al., 1996a; Purcell \& Arai, 2001; Costello \& Colin, 2002; Hansson et al., 2005; Hosia \& Båmstedt, 2007), and need further study. Because of the great morphological differences between scyphomedusae and hydromedusae, it is unlikely that hydromedusan feeding could be predicted by use of the semaeostome scyphomedusa regressions herein. Similarly, because of the great differences among hydromedusan species, algorithms would need to be developed that group species of similar morphology, feeding behavior, and diet, such as for anthomedusae and for leptomedusae. Among ctenophores, only coastal ctenophores, Pleurobrachia spp. and Mnemiopsis leidyi, have been studied relatively well because of their abundance and the ability to sample them with plankton nets. Because of their different feeding methods, a different feeding algorithm probably would be necessary for cydippid ctenophores (e.g., Pleurobrachia spp.) than for lobate ctenophores (e.g., M. leidyi).

The above analyses of feeding and metabolic rates of Aurelia spp. medusae from disparate habitats and Mnemiopsis leidyi ctenophores show that predictive algorithms can be developed. The ecology of Mnemiopsis leidyi is the same in its native (American Atlantic coasts) and introduced (Black Sea region) waters (e.g., reviewed in Kremer, 1994; Purcell et al., 2001b; Shiganova et al., 2003). The regressions herein could be used to predict its predators' effects in different habitats. This approach recently was used to estimate the predation impact of Chrysaora melanaster in the Bering Sea from the metabolic rates of Cyanea capillata (Brodeur et al., 2002), and of M. leidyi in Danish waters from previously determined clearance rates (Riisgård et al., 2007). The ecologies of tropical and sub-tropical jellyfish, including coronates (Kremer, 2005), rhizostomes (Uye, 2008; West et al., 2008), cubomedusae (Gordon \& Seymour, 2008), hydromedusae, siphonophores, and ctenophores (Kremer et al., 1986), generally have been studied less than temperate semaeostome scyphomedusae and M. leidyi; therefore, additional data on feeding and metabolic rates of those groups probably are needed before generalized algorithms are developed.

Specific comments on use of feeding data to estimate jellyfish and ctenophore predation

There is inherently greater variability among species in feeding rates (Figs. 1, 2, 4) than in metabolic rates (Figs. 6, 7) because of the differences in predator morphology, nematocysts, and behavior, as well as 
prey morphology and behavior (reviewed in Purcell, 1997). In addition to the inherent variation among species, our inability to precisely sample the prey population in which the predators fed contributes to variation in the data. The gut contents (prey medusa $^{-1}$ ) used here from various studies could have influenced variability because of different methodologies used. Medusae usually were dipped from the surface, but some were collected at depth by divers (Dawson \& Martin, 2001). Preservation time differed from 0 to $45 \mathrm{~min}$, which would affect the numbers of recognizable prey. Some studies preserved whole medusae (Purcell, 2003; Uye \& Shimauchi, 2005; Lo \& Chen, 2008), but others rinsed out gastric pouch contents (Dawson \& Martin, 2001; Lucas, unpublished), which could affect the numbers of prey retrieved. Plankton nets with different mesh-size (200 or $212 \mu \mathrm{m}$ in Lucas, unpublished; $243 \mu \mathrm{m}$ in Purcell, 2003; 10 and $100 \mu \mathrm{m}$ in Uye \& Shimauchi, 2005; $80 \mu \mathrm{m}$ in Dawson \& Martin, 2001) or a pump and $64 \mu \mathrm{m}$ mesh (Purcell, 1992) were used to sample available prey, which strongly affected estimates of prey density, and subsequent utility of the regressions. Use of zooplankton densities from $100-\mu \mathrm{m}$ and $330-\mu \mathrm{m}$ net samples gave different results in the Aurelia spp. regression (Table 3).

Despite obvious morphological dissimilarities among the semaeostome species tested here, different prey populations, and different methodologies, FR on copepod prey were reasonably well predicted (generally within a factor of 2) over wide ranges of predator size, prey density, and temperature (Figs. 1 and 2, Tables 2 and 3). The similarity in FR among four scyphozoan species suggests that FR of other species may be estimated from the predictive equation; however, the poor match for Chrysaora fuscescens measured and calculated FR indicates that caution is necessary. Only species of similar size and habitat may be appropriate. The greatest divergence among the data was for Aurelia aurita in Japan, where small Oithona spp. copepods were the predominant prey, while calanoids predominated in the other locations. Therefore, assessment of the prey available may be especially important when choosing which feeding regression to apply.

The present analyses only considered copepods, which are the most abundant prey in most situations; however, gelatinous species eat a variety of zooplankton taxa. Substitution of combined zooplankton taxa consumed by a predator instead of copepods $\mathrm{m}^{-3}$ in the regressions should also approximate total consumption. Alternatively, increasing consumption on copepods as calculated by the regressions by the percentages of other prey would approximate total consumption.

Although temperature did not significantly affect FR of Aurelia aurita medusae in different habitats, it significantly affected Chrysaora quinquecirrha FR in different seasons in Chesapeake Bay. Warm temperature could increase medusa swimming and digestion rates, as well as prey activity; therefore, although prey capture could increase, the prey in the gut contents may remain similar across temperatures because of more rapid digestion.

The length of time required for digestion of copepod prey decreased with Aurelia spp. medusa size and temperature. The effect of size mainly was due to the long times for ephyrae and very small medusae to digest large copepods. This regression could be used in combination with gut contents to calculate the feeding rates of Aurelia spp. medusae throughout their range of habitats.

Specific comments on use of metabolic rates to estimate jellyfish and ctenophore predation

Data compiled here show that jellyfish respiration scales with mass with an exponent of $\sim 1$ (Fig. 6 , Tables 8, 10). This is in agreement with previous conclusions for jellyfish and pelagic animals in general (e.g., Glazier, 2006); however, the empirical relationships for ctenophores were closer to 0.75 than 1 (Fig. 6, Tables 8, 10).

These analyses showed that respiration rates of scyphomedusae and Mnemiopsis leidyi ctenophores measured at or near ambient temperatures did not change with temperature in accordance with experimentally measured $\mathrm{Q}_{10} \mathrm{~s}$ (Fig. 7, Table 9). Although respiration rates increase when temperature is raised to measure $\mathrm{Q}_{10}$ and increase with ambient seasonal warming within a habitat, respiration rates in locations differing in ambient temperature did not reflect the laboratory-determined $\mathrm{Q}_{10} \mathrm{~s}$. $\mathrm{Q}_{10}$ of the combined Aurelia spp. data was only 1.67. Dawson \& Martin (2001) noted that the respiration rates of tropical $A$. aurita were similar to those of temperate A. aurita, even though the ambient temperatures were very different, and that temperature adaptation was 
common among other animals. Metabolic rates of Chrysaora quinquecirrha medusae also increased to some extent with temperature $\left(\mathrm{Q}_{10}=1.67\right)$ in Chesapeake Bay (Nemazie et al., 1993). Metabolic rates of $M$. leidyi ctenophores increased seasonally with temperature (combined data $\mathrm{Q}_{10}=1.33$ ), which is less than published $\mathrm{Q}_{10}$ s (Table 9). Similarly, metabolic rates of ctenophores from Biscayne Bay, Florida increased little with temperatures from 10 to $28^{\circ} \mathrm{C}$ (Baker, 1973, shown in Kremer, 1977). I conclude that the respiration rates of Aurelia spp., Chrysaora spp., and Cyanea spp. scyphomedusae, and $M$. leidyi ctenophores can be predicted from most habitats with the above regressions using mass, and that adjustment for temperature by $\mathrm{Q}_{10}$ determined from experimentally changed temperatures may misestimate metabolic rates. It is important to measure metabolic rates of the organisms at their ambient temperatures.

The prior feeding condition of the specimens also affects their metabolic rates. Variation in prior acclimation duration and feeding in the experiments used here contributed to their different results. Specimens were acclimated for one to several hours before measuring metabolism in most studies. Some studies used newly collected specimens to reflect rates in situ (e.g., Nemazie et al., 1993), while others explicitly tested the effects of food (e.g., Kremer, 1982; Møller \& Riisgård, 2007). High levels of food in the laboratory increased the metabolism of Aurelia aurita by 3.5 times (Møller \& Riisgård, 2007), but that may not be representative of metabolic rates in situ. Metabolic rates of newly collected, lightly fed, and heavily fed specimens of a small siphonophore species showed that the newly collected and lightly fed rates were identical, while the heavily fed rates were higher (Purcell \& Kremer, 1983). Therefore, I conclude that the metabolic rates that most resemble in situ rates are those measured on newly collected specimens at ambient temperatures.

A weakness of using metabolic rates to estimate ingestion is that metabolic rates usually do not account for requirements for growth or reproduction, and thus are underestimates (see Møller \& Riisgård, 2007). Growth rates of scyphomedusae in situ were about 7\% WW d ${ }^{-1}$ (Schneider, 1989; Omori et al., 1995; Lucas, 1996; Uye \& Shimauchi, 2005). Therefore, increasing the metabolic rates by $7 \%$ for $\mathrm{WW}$, by $0.2 \%$ for $\mathrm{DW}$, and by $0.015 \%$ for $\mathrm{C}$ over basal rates for trophic estimates may be appropriate. Maximal in situ growth of Chrysaora quinquecirrha was $60 \%$ diameter $\mathrm{d}^{-1}\left(=25 \% \mathrm{C} \mathrm{d}^{-1}\right.$; Olesen et al., 1996). Adjustment for growth would depend on food availability, and would be time- and location-specific.

\section{Conclusions}

The above algorithms would allow estimation of feeding effects, generally within a factor of two, without extensive collection of in situ data on jellyfish or ctenophore feeding. The combined regressions predicted feeding and metabolic rates nearly as well as the local regressions. That seems like a reasonable level of uncertainty, given that all other biological measurements probably have the same or greater errors. Population data for Aurelia spp., Chrysaora quinquecirrha, Cyanea capillata, and Mnemiopsis leidyi densities, mean individual mass, zooplankton densities, and water temperature could be used to estimate feeding and respiration rates and consequent effects on the zooplankton population. In general, estimation of consumption by the metabolic regressions probably has less error than estimation from the feeding regressions. These algorithms should be tested for other species to determine how broadly they can be applied. New algorithms should be developed for other key gelatinous taxa, and analyses conducted on combined data from other species. Although these methods are approximate, and Arai (1997) cautions against such extrapolation, it is important that gelatinous species be included in ecosystem studies and models that now are conducted on regional to global scales (Pauly et al., this volume). These methods offer alternatives to when limited person-power, resources, and time do not permit exhaustive in situ collection of jellyfish feeding data. I briefly summarize recommendations for trophic research methods for gelatinous predators:

- Determine densities and size distributions (mass) of the gelatinous species.

- Sample small ctenophores and hydromedusae as well as large scyphomedusae. Three types of sampling may be necessary-nets as small 0.5$\mathrm{m}$-diameter can be sufficient for hydromedusae, short tows of soft-mesh plankton net with a non-draining cod-end improve sampling for 
ctenophores, and plankton nets larger than 1-m-diameter are required for scyphomedusae.

- Test the accuracy of the various large-scale sampling methods against quantitative methods, and develop conversions to make methods as quantitative as possible.

- Use a fine-mesh net $(\sim 100 \mu \mathrm{m})$ for zooplankton sampling.

- Report temperature and salinity.

- Use the gut-content method to estimate the feeding rates on mesozooplankton.

- For clearance rate experiments use high container-to-specimen volume ratios, at least 2,500:1.

- Use natural prey, not Artemia sp. nauplii, in feeding experiments.

- Use ambient temperature for all feeding, digestion, and metabolic experiments.

- Conduct metabolic experiments on newly collected specimens for rates that reflect natural food conditions.

- Do not convert metabolic rates by use of $\mathrm{Q}_{10}$ values measured at experimentally manipulated temperatures.

- Before sampling, examine the data criteria of a central database and submit data to a central database after publication.

- Develop algorithms among taxa that can be used to predict gelatinous predator effects on large scales.

Acknowledgments I thank Drs K. A. Pitt and J. Seymour for the opportunity to speak at the Second International Jellyfish Blooms Symposium. I especially thank Drs. M. N Dawson, L. E. Martin, W.-T. Lo, C. H. Lucas, S.-I. Uye, M. B. Decker, P. Kremer, M. R. Reeve, and C. L. Suchman for use of raw data, and A. G. Hirst, P. Kremer, M. N Dawson, and an anonymous reviewer for suggestions. Studies in Chesapeake Bay were funded by NOAA grants NA86AA-D-SG006 and NA890AA-D-SG063 to the University of Maryland Sea Grant Program, and NSF grant no. DEB-9412113 to the TIES group and by NSF grant no. OCE-9633607 to the author. The research in Alaska was funded by the Exxon Valdez Oil Spill Trustee Council as part of the Alaska Predator Ecosystem eXperiment (APEX Projects 96163A, 97163A, 98163A, 98163S, and 99163S). This review was partially prepared while the author was supported by grants from the National Science Council and the Ministry of Education of the Republic of China to Dr. W.-T. Lo [NSC91-2621-Z 110-001, 94-C030220 (Kuroshio project)]. I dedicate this article to Hoyt Purcell, my champion.

Open Access This article is distributed under the terms of the Creative Commons Attribution Noncommercial License which permits any noncommercial use, distribution, and reproduction in any medium, provided the original author(s) and source are credited.

\section{References}

Anninsky, B. E., Z. A. Romanova, G. I. Abolmasova, A. C. Gucu \& A. E. Kideys, 1998. The ecological and physiological state of the ctenophore Mnemiopsis leidyi (Agassiz) in the Black Sea in autumn 1996. In Ivanov, L. I. \& T. Oguz (eds), Ecosystem Modeling as a Management Tool for the Black Sea. Kluwer Academic Publishers, Dordecht: 249-262.

Arai, M. N., 1997. Coelenterates in pelagic food webs. In den Hartog, J. C. (ed.), Proceeding of the 6th International Conference on Coelenterate Biology. Publication of the National Natuurhistorisch Museum, Leiden: 1-9.

Arai, M. N., 2005. Predation on pelagic coelenterates: a review. Journal of the Marine Biological Association of the United Kingdom 85: 523-536.

Arai, M. N., D. W. Welch, A. L. Dunsmuir, M. C. Jacobs \& A. R. Ladouceur, 2003. Digestion of pelagic Ctenophora and Cnidaria by fish. Canadian Journal of Fisheries and Aquatic Sciences 60: 825-829.

Attrill, M. J., J. Wright \& M. Edwards, 2007. Climate-related increases in jellyfish frequency suggest a more gelatinous future for the North Sea. Limnology and Oceanography 52: 480-485.

Baird, D. \& R. E. Ulanowicz, 1989. The seasonal dynamics of the Chesapeake Bay ecosystem. Ecological Monographs 59: 329-364.

Baker, L. D., 1973. The ecology of the ctenophore Mnemiopsis mccradyi Mayer, in Biscayne Bay, Florida, 131 pp. M.S. Thesis, University of Miami.

Båmstedt, U., S. Kaartvedt \& M. Youngbluth, 2003. An evaluation of acoustic and video methods to estimate the abundance and vertical distribution of jellyfish. Journal of Plankton Research 25: 1307-1318.

Benson, S. R., P. H. Dutton, C. Hitipeuw, B. Samber, J. Bakarbessy \& D. Parker, 2007. Post-nesting migrations of leatherback turtles (Dermochelys coriacea) from Janiursba-Medi, Bird's Head Peninsula, Indonesia. Chelonian Conservation and Biology 6: 150-154.

Bernard, P., F. Couasnon, J.-P. Soubiran \& J.-F. Goujon, 1988. Surveillance estivale de la méduse Pelagia noctiluca (Cnidaria, Scyphozoa) sur les côtes Méditerranéennes Françaises. Annales de l'Institut océanographique, Paris 64: 115-125.

Boersma, M., A. M. Malzahn, W. Greve \& J. Javidpour, 2007. The first occurrence of the ctenophore Mnemiopsis leidyi in the North Sea. Helgoland Marine Research 61: 153-155.

Bouillon, J. \& F. Boero, 2000. The Hydrozoa: a new classification in the light of old knowledge. Thalassia Salentina 24: 3-296.

Brierley, A. S., B. E. Axelsen, D. C. Boyer, C. P. Lynam, C. A. Didcock, H. J. Boyer, C. A. J. Sparks, J. E. Purcell \& M. J. Gibbons, 2004. Single-target echo detections of jellyfish. ICES Journal of Marine Science 61: 383-393.

Brodeur, R. D., M. B. Decker, L. Ciannelli, J. E. Purcell, N. A. Bond, P. J. Stabeno, E. Acuna \& G. L. Hunt Jr., 2008a. The rise and fall of jellyfish in the Bering Sea in relation to climate regime shifts. Progress in Oceanography 77: 103-111. 
Brodeur, R. D., C. E. Mills, J. E. Overland \& J. D. Shumacher, 1999. Evidence for a substantial increase in gelatinous zooplankton in the Bering Sea, with possible links to climate change. Fisheries Oceanography 8: 296-306.

Brodeur, R. D., C. L. Suchman, D. C. Reese, T. W. Miller \& E. A. Daly, 2008b. Spatial overlap and trophic interactions between pelagic fish and large jellyfish in the northern California current. Marine Biology 154: 649-659.

Brodeur, R. D., S. Sugisaki \& G. L. Hunt Jr., 2002. Increases in jellyfish biomass in the Bering Sea: implications for the ecosystem. Marine Ecology Progress Series 233: 89-103.

Brown, C. W., R. R. Hood, Z. Li, M. B. Decker, T. Gross, J. E. Purcell \& H. Wang, 2002. Forecasting system predicts presence of sea nettles in Chesapeake Bay. EOS, Transactions of the American Geophysical Union 83: 321, 325-326.

Brown, E. D., S. M. Moreland, B. L. Norcross \& G. A. Borstad, 1999. Estimating forage fish and seabird distribution and abundance using aerial surveys: survey design and uncertainty. In Cooney, R. T. (ed.), Sound Ecosystem Assessment (SEA)-An Integrated Science Plan for the Restoration of Injured Species in Prince William Sound. Exxon Valdez Oil Spill Restoration Project Final Report (Restoration Project 99320T), Anchorage: 131-172.

Bunker, A. J. \& A. G. Hirst, 2004. Fecundity of marine planktonic copepods: global rates and patterns in relation to chlorophyll a, temperature and body weight. Marine Ecology Progress Series 279: 161-181.

Cargo, D. G. \& D. R. King, 1990. Forecasting the abundance of the sea nettle, Chrysaora quinquecirrha, in the Chesapeake Bay. Estuaries 13: 486-491.

Colin, S. P., J. H. Costello, W. M. Graham \& J. Higgins III, 2005. Omnivory by the small cosmopolitan hydromedusa Aglaura hemistoma. Limnology and Oceanography 50: 1264-1268.

Colombo, G. A., A. Benović, A. Majej, D. Lučić, T. Makovec, V. Onofri, M. Achal, A. Madirolas \& H. Mianzan, 2008. Acoustic survey of a jellyfish-dominated ecosystem (Mljet, Croatia). Hydrobiologia. doi:10.1007/s10750-0089587-6.

Colombo, G. A., H. Mianzan \& A. Madirolas, 2003. Acoustic characterization of gelatinous-plankton aggregations: four case studies from the Argentine continental shelf. ICES Journal of Marine Science 60: 650-657.

Costello, J. H. \& S. P. Colin, 2002. Prey resource utilization by co-occurring hydromedusae from Friday Harbor, Washington, USA. Limnology and Oceanography 47: 934-942.

D'Ambra, I., J. H. Costello \& F. Bentivegna, 2001. Flow and prey capture by the scyphomedusa Phyllorhiza punctata von Lendenfeld, 1884. Hydrobiologia 451 (Developments in Hydrobiology 155): 223-227.

Dawson, M. N. \& L. E. Martin, 2001. Geographic variation and ecological adaptation in Aurelia (Scyphozoa, Semaeostomeae): some implications from molecular phylogenetics. Hydrobiologia 451 (Developments in Hydrobiology 155): 259-273.

Decker, M. B., D. L. Breitburg \& J. E. Purcell, 2004. Effects of low dissolved oxygen on zooplankton predation by the ctenophore, Mnemiopsis leidyi. Marine Ecology Progress Series 280: 163-172.
Decker, M. B., C. W. Brown, R. R. Hood, J. E. Purcell, T. F. Gross, J. Matanoski \& R. Owens, 2007. Development of habitat models for predicting the distribution of the scyphomedusa, Chrysaora quinquecirrha, in Chesapeake Bay. Marine Ecology Progress Series 329: 99-113.

Dong, J., L.-x. Jiang, K.-f. Tan, H.-y. Liu, J. E. Purcell, P.-j. Li \& C.-c. Ye., 2008. Stock enhancement of the edible jellyfish (Rhopilema esculentum Kishinouye) in Liaodong Bay, China: a review. Hydrobiologia. doi:10.1007/ s10750-008-9592-9.

Doyle, T. K., J. D. R. Houghton, S. M. Buckley, G. C. Hays \& J. Davenport, 2007. The broad-scale distribution of five jellyfish species across a temperate coastal environment. Hydrobiologia 579: 29-39.

Finenko, G. A., G. I. Abolmasova \& Z. A. Romanova, 1995. Intensity of the nutrition, respiration and growth of Mnemiopsis mccradyi in relation to grazing conditions. Biologia Morya 21: 315-320 (in Russian).

Finenko, G. A., A. E. Kideys, B. E. Anninsky, T. A. Shiganova, A. Roohi, M. R. Tabari, H. Rostami \& S. Bagheri, 2006. Invasive ctenophore Mnemiopsis leidyi in the Caspian Sea: feeding, respiration, reproduction and predatory impact on the zooplankton community. Marine Ecology Progress Series 314: 171-185.

Fuji, N., A. Fukushima, Y. Naojo \& H. Takeoka, 2007. Aggregation of Aurelia aurita in Uwa Sea, Japan. In Tanabe, S., H. Takeoka, T. Isobe \& Y. Nishibe (eds), Chemical Pollution and Environmental Changes. Frontiers Science Series, Vol. 48. Universal Academy Press, Inc., Tokyo: 379-381.

Gibbons, M. J. \& A. J. Richardson, 2008. Patterns in pelagic cnidarian abundance in the North Atlantic. Hydrobiologia (in press).

Glazier, D. S., 2006. The 3/4-power law is not universal: evolution of isometric, ontogenetic metabolic scaling in pelagic animals. BioScience 56: 325-332.

Gordon, M. \& J. Seymour, 2008. Quantifying movement patterns in the tropical Australian Chirodropid Chironex fleckeri using ultrasonic telemetry. Hydrobiologia (in press).

Goy, J., P. Morand \& M. Etienne, 1989. Long-term fluctuations of Pelagia noctiluca (Cnidaria, Scyphomedusa) in the western Mediterranean Sea. Prediction by climatic variables. Deep-Sea Research 36: 269-279.

Graham, W. M., 2001. Numerical increases and distributional shifts of Chrysaora quinquecirrha (Desor) and Aurelia aurita (Linné) (Cnidaria: Scyphozoa) in the northern Gulf of Mexico. Hydrobiologia 451 (Developments in Hydrobiology 155): 97-111.

Graham, W. M., D. L. Martin, D. L. Felder, V. L. Asper \& H. M. Perry, 2003a. Ecological and economic implications of the tropical jellyfish invader, Phyllorhiza punctata von Lendenfeld, in the northern Gulf of Mexico. Biological Invasions 5: 53-69.

Graham, W. M., D. L. Martin \& J. C. Martin, 2003b. In situ quantification and analysis of large jellyfish using a novel video profiler. Marine Ecology Progress Series 254: 129-140.

Hansen, P. J., P. K. Bjørnsen \& B. W. Hansen, 1997. Zooplankton grazing and growth: scaling within the 
$2-2,000-\mu \mathrm{m}$ body size range. Limnology and Oceanography 42: 687-704.

Hansson, L. J., O. Moeslund, T. Kiørboe \& H. U. Riisgård, 2005. Clearance rates of jellyfish and their potential predation impact on zooplankton and fish larvae in a neritic ecosystem (Limfjorden, Denmark). Marine Ecology Progress Series 204: 117-131.

Hays, G. C., T. K. Doyle, J. D. R. Houghton, M. K. S. Lilley, J. D. Metcalfe \& D. Righton, 2008. Diving behaviour of jellyfish equipped with electronic tags. Journal of Plankton Research 30: 325-331.

Hirst, A. G. \& A. J. Bunker, 2003. Growth of marine plankton copepods: global rates and patterns in relation to chlorophyll a, temperature, and body weight. Limnology and Oceanography 48: 1988-2010.

Hirst, A. G. \& T. Kiørboe, 2002. Mortality of marine planktonic copepods: global rates and patterns. Marine Ecology Progress Series 230: 195-209.

Hirst, A. G. \& C. H. Lucas, 1998. Salinity influences body weight quantification in the scyphomedusa Aurelia aurita: important implication for body weight determination in gelatinous zooplankton. Marine Ecology Progress Series 165: 259-269.

Hirst, A. G., J. C. Roff \& R. S. Lampitt, 2003. A synthesis of growth rates in marine epipelagic invertebrate zooplankton. Advances in Marine Biology 44: 1-142.

Hosia, A. \& U. Båmstedt, 2007. Seasonal changes in the gelatinous zooplankton community and hydromedusa abundances in Korsfjord and Fanafjord, western Norway. Marine Ecology Progress Series 351: 113-127.

Houghton, J. D. R., T. K. Doyle, J. Davenport \& G. C. Hays, 2006. Developing a simple, rapid method for identifying and monitoring jellyfish aggregations from the air. Marine Ecology Progress Series 314: 139-170.

Houghton, J. D. R., T. K. Doyle, J. Davenport, M. K. S. Lilley, R. P. Wilson \& G. C. Hays, 2007. Stranding events provide indirect insights into the seasonality and persistence of jellyfish medusae (Cnidaria: Scyphozoa). Hydrobiologia 589: 1-13.

ICES, 2000. ICES Zooplankton Methodology Manual. Academic Press, London: 705.

Ishii, H. \& F. Tanaka, 2001. Food and feeding of Aurelia aurita in Tokyo Bay with an analysis of stomach contents and a measurement of digestion times. Hydrobiologia 451 (Developments in Hydrobiology 155): 311-320.

Ishii, H. \& F. Tanaka, 2006. Respiration rates and metabolic demands of Aurelia aurita in Tokyo Bay with special reference to large medusae. Plankton and Benthos Research 1: 64-67.

Kaartvedt, S., T. A. Klevjer, T. Torgersen, T. A. Sørnes \& A. Røstad, 2007. Diel vertical migration of individual jellyfish (Periphylla periphylla). Limnology and Oceanography 52: 975-983.

Kirby, R. R. \& J. A. Lindley, 2005. Molecular analysis of continuous plankton recorder samples, an examination of echinoderm larvae in the North Sea. Journal of the Marine Biological Association of the United Kingdom 85: 451-459.

Kohama, T., N. Shinya, N. Okuda, H. Miyasaka \& H. Takeoka, 2006, Estimation of trophic level of Aurelia aurita using stable isotope ratios in Uwa Sea, Japan. Proceedings of the
COE International Symposium 2006 Pioneering Studies of Young Scientists on Chemical Pollution and Environmental Changes. Ehime University, Japan.

Kremer, P., 1976. Population dynamics and ecological energetics of a pulsed zooplankton predator, the ctenophore Mnemiopsis leidyi. In Wiley, M. L. (ed.), Estuarine Processes, Vol. 1. Uses, Stresses, and Adaptation to the Estuary. Academic Press, New York:197-215.

Kremer, P., 1977. Respiration and excretion by the ctenophore Mnemiopsis leidyi. Marine Biology 44: 43-50.

Kremer, P., 1982. Effect of food availability on the metabolism of the ctenophore Mnemiopsis mccradyi. Marine Biology 71: 149-156.

Kremer, P., 1994. Patterns of abundance for Mnemiopsis in U.S. coastal waters: a comparative overview. ICES Journal of Marine Science 51: 347-354.

Kremer, P., 2005. Ingestion and elemental budgets for Linuche unguiculata, a scyphomedusae with zooxanthellae. Journal of the Marine Biological Association of the United Kingdom 85: 613-625.

Kremer, J. N. \& P. Kremer, 1982. A three trophic level estuarine model: synergism of two mechanistic simulations. Ecological Modelling 15: 145-157.

Kremer, P. \& M. R. Reeve, 1989. Growth dynamics of a ctenophore (Mnemiopsis) in relation to variable food supply. II. Carbon budgets and growth model. Journal of Plankton Research 11: 553-574.

Kremer, P., M. R. Reeve \& M. A. Syms, 1986. The nutritional ecology of the ctenophore Bolinopsis vitrea: comparisons with Mnemiopsis mccradyi from the same region. Journal of Plankton Research 8: 1197-1208.

Larson, R. J., 1986. Water content, organic content, and carbon and nitrogen composition of medusae from the northeast Pacific. Journal of Experimental Marine Biology and Ecology 99: 107-120.

Larson, R. J., 1987. Respiration and carbon turnover rates of medusae from the NE Pacific. Comparative Biochemistry and Physiology A 87: 93-100.

Larson, R. J., 1991. Diet, prey selection and daily ration of Stomolophus meleagris, a filter-feeding scyphomedusa from the NE Gulf of Mexico. Estuarine and Coastal Shelf Science 32: 511-525.

Link, J. S. \& M. D. Ford, 2006. Widespread and persistent increase of Ctenophora in the continental shelf ecosystem off NE USA. Marine Ecology Progress Series 320: $153-159$.

Liu, C.-Y. \& Y.-P. Bi, 2006. A method of recapture rate in jellyfish ranching. Fishery Science/Shuichan Kexue 25: 150-151.

Lo, W.-T. \& I.-L. Chen, 2008. Population succession and feeding of scyphomedusae, Aurelia aurita, in a eutrophic tropical lagoon in Taiwan. Estuarine Coastal and Shelf Science. 76: 227-238.

Lucas, C. H., 1996. Population dynamics of Aurelia aurita (Scyphozoa) from an isolated brackish lake, with particular reference to sexual reproduction. Journal of Plankton Research 18: 987-1007.

Lynam, C. P., M. J. Gibbons, B. E. Axelsen, C. A. J. Sparks, J. Coetzee, B. G. Heywood \& A. S. Brierley, 2006. Jellyfish overtake fish in a heavily fished ecosystem. Current Biology 16: R492-R493. 
Lynam, C. P., S. J. Hay \& A. S. Brierley, 2004. Interannual variability in abundance of North Sea jellyfish and links to the North Atlantic Oscillation. Limnology and Oceanography 49: 637-643.

Lynam, C. P., M. R. Heath, S. J. Hay \& A. S. Brierley, 2005. Evidence for impacts by jellyfish on North Sea herring recruitment. Marine Ecology Progress Series 298: 157-167.

Mackie, G. O. \& C. E. Mills, 1983. Use of the pisces IV submersible for zooplankton studies in coastal waters of British Columbia. Canadian Journal of Fisheries and Aquatic Sciences 40: 763-776.

Mackie, G. O., P. R. Pugh \& J. E. Purcell, 1987. Siphonophore biology. Advances in Marine Biology 24: 97-262.

Marrari, M., C. Hu \& K. Daly, 2006. Validation of SeaWiFS chlorophyll a concentrations in the Southern Ocean: a revisit. Remote Sensing of Environment 105: 367-375.

Martinussen, M. B. \& U. Båmstedt, 1999. Nutritional ecology of gelatinous planktonic predators. Digestion rate in relation to type and amount of prey. Journal of Experimental Marine Ecology and Biology 232: 61-84.

Martinussen, M. B. \& U. Båmstedt, 2001. Digestion rate in relation to temperature of two gelatinous planktonic predators. Sarsia 86: 21-35.

Matsakis, S. \& R. J. Conover, 1991. Abundance and feeding of medusae and their potential impact as predators on other zooplankton in Bedford Basin (Nova Scotia Canada) during spring. Canadian Journal of Fisheries and Aquatic Sciences 48: 1419-1430.

Mianzan, H. W., 1999. Ctenophora. In Boltovskay, D. (ed.), South Atlantic Zooplankton. Backhuys Publishers, Leiden: 561-573.

Mianzan, H. W. \& P. F. S. Cornelius, 1999. Cubomedusae and Scyphomedusae. In Boltovskay, D. (ed.), South Atlantic Zooplankton. Backhuys Publishers, Leiden: 513-559.

Miller, R. J., 1970. Distribution and energetics of an estuarine population of the ctenophore, Mnemiopsis leidyi. Ph.D. Thesis, Department of Zoology, North Carolina State University, Raleigh.

Molinero, J. C., F. Ibanez, P. Nival, E. Buecher \& S. Souissi, 2005. North Atlantic climate and northwestern Mediterranean plankton variability. Limnology and Oceanography 50: 1213-1220.

Møller, L. F. \& H. U. Riisgård, 2007. Respiration in the scyphozoan jellyfish Aurelia aurita and two hydromedusae (Sarsia tubulosa and Aequorea vitrina): effect of size, temperature and growth. Marine Ecology Progress Series 330: 149-154.

Montoya, J. P., S. G. Horrigan \& J. J. McCarthy, 1990. Natural abundance of ${ }^{15} \mathrm{~N}$ in particulate nitrogen and zooplankton in the Chesapeake Bay. Marine Ecology Progress Series 65: 35-61.

Nemazie, D. A., J. E. Purcell \& P. M. Glibert, 1993. Ammonium excretion by gelatinous zooplankton and their contribution to the ammonium requirements of microplankton in Chesapeake Bay. Marine Biology 116: 451-458.

Oguz, T., 2005a. Black Sea ecosystem response to climatic teleconnections. Oceanography 18: 122-133.

Oguz, T., 2005b. Long-term impacts of anthropogenic forcing on the Black Sea ecosystem. Oceanography 18: 112-121.
Oguz, T., H. W. Ducklow, J. E. Purcell \& P. MalanotteRizzoli, 2001. Modeling the response of top-down control exerted by gelatinous carnivores in the Black Sea pelagic food web. Journal of Geophysical Research 106: 4543-4564.

Olesen, N. J., J. E. Purcell \& D. K. Stoecker, 1996. Feeding and growth by ephyrae of scyphomedusae Chrysaora quinquecirrha. Marine Ecology Progress Series 137: 149-159.

Omori, M. \& E. Nakano, 2001. Jellyfish fisheries in southeast Asia. Hydrobiologia 451 (Developments in Hydrobiology 155): 19-26.

Omori, M., H. Ishii \& A. Fujinaga, 1995. Life history strategy of Aurelia aurita (Cnidaria, Scyphomedusae) and its impact on the zooplankton community of Tokyo Bay. ICES Journal of Marine Science 52: 597-603.

Pagès, F., H. E. González \& S. R. González, 1996a. Diet of the gelatinous zooplankton in Hardangerfjord (Norway) and potential predatory impact by Aglantha digitale (Trachymedusae). Marine Ecology Progress Series 139: 69-77.

Pagès, F., M. G. White \& P. G. Rodhouse, 1996b. Abundance of gelatinous carnivores in the nekton community of the Antarctic Polar Frontal Zone in summer 1994. Marine Ecology Progress Series 141: 139-147.

Palomares, M. L. D. \& D. Pauly, 2008. The growth of jellyfishes. Hydrobiologia. doi:10.1007/s10750-008-9582-y.

Pauly, D., W. M. Graham, S. Libralato, L. Morissette \& M. L. D. Palomares, 2008. Jellyfish in ecosystems, online databases and ecosystem models. Hydrobiologia. doi:10.1007/s10750-008-9583-x.

Pavlova, E. V. \& N. I. Minkina, 1993. The respiration rate of the Black Sea invader ctenophore (Ctenophora. Lobata: Mnemiopsis) Dokl. RAS 333(5): 682-683.

Pitt, K. A., A.-L. Clement, R. M. Connolly \& D. ThibaultBotha, 2008a. Predation by jellyfish on large and emergent zooplankton: implications for benthic-pelagic coupling. Estuarine, Coastal and Shelf Science 76: 827-833.

Pitt, K. A., R. M. Connolly \& T. Meziane, 2008b. Stable isotope and fatty acid tracers in energy and nutrient studies of jellyfish: a review. Hydrobiologia. doi:10.1007/s10750008-9581-z.

Pitt, K. A. \& M. J. Kingsford, 2003. Temporal variation in the virgin biomass of the edible jellyfish, Catostylus mosaicus (Scyphozoa, Rhizostomeae). Fisheries Research 63: 303-313.

Pitt, K. A., M. J. Kingsford, D. Rissik \& K. Koop, 2007. Jellyfish modify the response of planktonic assemblages to nutrient pulses. Marine Ecology Progress Series 351: $1-13$.

Pitt, K. A., K. Koop \& D. Rissik, 2005. Contrasting contributions to inorganic nutrient recycling by the co-occurring jellyfishes, Catostylus mosaicus and Phyllorhiza punctata (Scyphosoa, Rhizostomeae). Journal of Experimental Marine Biology and Ecology 315: 71-86.

Pitt, K. A., D. T. Welsh \& R. H. Condon, 2008c. Influence of jellyfish blooms on carbon, nitrogen and phosphorus cycling and plankton production. Hydrobiologia. doi:10.1007/s10750-008-9584-9.

Pugh, P. R., 1999. Siphonophorae. In Boltovskay, D. (ed.), South Atlantic Zooplankton. Backhuys Publishers, Leiden: 467-511. 
Purcell, J. E., 1988. Quantification of Mnemiopsis leidyi (Ctenophora, Lobata) from formalin-preserved plankton samples. Marine Ecology Progress Series 45: 197-200.

Purcell, J. E., 1992. Effects of predation by the scyphomedusan Chrysaora quinquecirrha on zooplankton populations in Chesapeake Bay. Marine Ecology Progress Series 87: 65-76.

Purcell, J. E., 1997. Pelagic cnidarians and ctenophores as predators: selective predation, feeding rates and effects on prey populations. Annales de l'Institut océanographique, Paris 73: $125-137$.

Purcell, J. E., 2003. Predation on zooplankton by large jellyfish (Aurelia labiata, Cyanea capillata, Aequorea aequorea) in Prince William Sound, Alaska. Marine Ecology Progress Series 246: 137-152.

Purcell, J. E. \& M. N. Arai, 2001. Interactions of pelagic cnidarians and ctenophores with fishes: a review. Hydrobiologia 451 (Developments in Hydrobiology 155): 27-44.

Purcell, J. E., D. L. Breitburg, M. B. Decker, W. M. Graham, M. J. Youngbluth \& K. A. Raskoff, 2001a. Pelagic cnidarians and ctenophores in low dissolved oxygen environments: a review. In Rabalais, N. N. \& R. E. Turner (eds), Estuarine Studies 58: Coastal Hypoxia: Consequences for Living Resources and Ecosystems. American Geophysical Union, Washington, DC: 77-100.

Purcell, J. E., E. D. Brown, K. D. E. Stokesbury, L. H. Haldorson \& T. C. Shirley, 2000. Aggregations of the jellyfish Aurelia labiata: abundance, distribution, association with age- 0 walleye pollock, and behaviors promoting aggregation in Prince William Sound, Alaska, USA. Marine Ecology Progress Series 195: 145-158.

Purcell, J. E. \& M. B. Decker, 2005. Effects of climate on relative predation by scyphomedusae and ctenophores on copepods in Chesapeake Bay during 1987-2000. Limnology and Oceanography 50: 376-387.

Purcell, J. E. \& P. Kremer, 1983. Feeding and metabolism of the siphonophore Sphaeronectes gracilis. Journal of Plankton Research 5: 95-106.

Purcell, J. E., T. A. Shiganova, M. B. Decker \& E. D. Houde, 2001b. The ctenophore Mnemiopsis in native and exotic habitats: U.S. estuaries versus the Black Sea basin. Hydrobiologia 451 (Developments in Hydrobiology 155): 145-176.

Purcell, J. E., S.-I. Uye \& W.-T. Lo, 2007. Anthropogenic causes of jellyfish blooms and direct consequences for humans: a review. Marine Ecology Progress Series 350: 153-174.

Purcell, J. E., T. E. Whitledge, K. N. Kosobokova \& R. R. Hopcroft. Distribution, abundance, and predation effects of epipelagic ctenophores and jellyfish in the western Arctic Ocean. Deep-Sea Research II (in press).

Rapoza, R., D. Novak \& J. H. Costello, 2006. Life-stage dependent, in situ dietary patterns of the lobate ctenophore Mnemiopsis leidyi Agassiz 1865. Journal of Plankton Research 27: 951-956.

Raskoff, K. A., 2001. The impact of El Niño events on blooms of mesopelagic hydromedusae. Hydrobiologia 451: 121-129.

Raskoff, K. A., 2003. Collection and culture techniques for gelatinous zooplankton. Biological Bulletin 204: 68-80.
Raskoff, K. A., R. R. Hopcroft, J. E. Purcell \& M. J. Youngbluth. Jellies on ice: ROV observations from the Arctic 2005 Hidden Ocean Expedition. Deep-Sea Research II (in press).

Raskoff, K. A., J. E. Purcell \& R. R. Hopcroft, 2005. Gelatinous zooplankton of the Arctic Ocean: in situ observations under the ice. Polar Biology 28: 207-217.

Riisgård, H. U., L. Bøttiger, C. V. Madsen \& J. E. Purcell, 2007. Invasive ctenophore Mnemiopsis leidyi in Limfjorden (Denmark) in late summer 2007-assessment of abundance and predation effects. Aquatic Invasions 2: 395-401.

Rutherford, L. D. Jr. \& E. V. Thuesen, 2005. Metabolic performance and survival of medusae in estuarine hypoxia. Marine Ecology Progress Series 294: 189-200.

Ruzicka, J. J., R. D. Broudeur \& T. C. Wainwright, 2007. Seasonal food web wodels for the Oregon inner-shelf ecosystem; investigating the role of large jellyfish. CalCOFI Reports 48: 106-128.

Schneider, G., 1989. A comparison of carbon based ammonia excretion rates between gelatinous and non-gelatinous zooplankton: implications and consequences. Marine Biology 106: 219-225.

Seymour, J. E., T. J. Carrette \& P. A. Sutherland, 2004. Do box jellyfish sleep at night? Medical Journal of Australia 181: 707.

Shiganova, T. A., et al., 2003. Ctenophore invaders Mnemiopsis leidyi (A. Agassiz), Beroe ovata Mayer 1912, and their effect on the pelagic ecosystem of the northern Black Sea. Biological Bulletin 2: 225-235.

Siferd, T. D. \& R. J. Conover, 1992. Natural history of ctenophores in the resolute passage area of the Canadian High Arctic with special reference to Mertensia ovum. Marine Ecology Progress Series 86: 133-144.

Sparks, C., E. Buecher, A. S. Brierley, B. E. Axelsen, H. Boyer \& M. J. Gibbons, 2001. Observation on the distribution and relative abundance of the scyphomedusan Chrysaora hysoscella (Linné, 1766) and the hydrozoan Aequorea aequorea (Forskål, 1775) in the northern Benguela ecosystem. Hydrobiologia 451 (Developments in Hydrobiology 155): 275-286.

SPSS, 1997. SigmaStat ${ }^{\circledR} 2.0$ for Windows ${ }^{\circledR}$ User's Manual. SPSS Inc., Chicago.

Stoecker, D. K., A. E. Michaels \& L. H. Davis, 1987b. Grazing by the jellyfish Aurelia aurita on mirozooplankton. Journal of Plankton Research 9: 901-915.

Stoecker, D. K., P. G. Verity, A. E. Michaels, L. H. Davis, 1987a. Feeding by larval and post-larval ctenophores on microzooplankton. Journal of Plankton Research 9: 667-683.

Suchman, C. L., E. A. Daly, J. E. Keister, W. T. Peterson \& R. D. Brodeur, 2008. Feeding patterns and predation potential of scyphomedusae in a highly productive upwelling region. Marine Ecology Progress Series 358: 161-172.

Sullivan, B. K., J. R. Garcia \& G. Klein-MacPhee, 1994. Prey selection by the scyphomedusa predator Aurelia aurita. Marine Biology 121: 335-341.

Sullivan, L. J. \& D. J. Gifford, 2004. Diet of the larval ctenophore Mnemiopsis leidyi A. Agassiz (Ctenophora, Lobata). Journal of Plankton Research 26: 417-431.

Sullivan, B. K. \& M. R. Reeve, 1982. Comparison of estimates of the predatory impact of ctenophores by two independent techniques. Marine Biology 68: 61-65. 
Toonen, R. H. \& F.-S. Chia, 1993. Limitations of laboratory assessments of coelenterate predation: container effects on the prey selection of the limnomedusa, Proboscidactyla flavicirrata (Brandt). Journal of Experimental Marine Biology and Ecology 167: 215-235.

Toyokawa, M., T. Inagaki \& M. Terazaki, 1997. Distribution of Aurelia aurita (Linnaeus, 1758) in Tokio Bay; observations with echosounder and plankton net. Proceedings of the 6th International Conference on Coelenterate Biology. Natuurhistorisch Museum, Leiden: 483-490.

Uye, S., 2008. Blooms of the giant jellyfish Nemopilema nomurai: a threat to the fisheries sustainability of the East Asian Marginal Seas. Plankton and Benthos Research 3 (Suppl.): 125-131.

Uye, S.-I., N. Fujii \& H. Takeoka, 2003. Unusual aggregations of the scyphomedusa Aurelia aurita in coastal waters along western Shikoku, Japan. Plankton Biology and Ecology 50: 17-21.

Uye, S. \& H. Shimauchi, 2005. Population biomass, feeding, respiration and growth rates, and carbon budget of the scyphomedusa Aurelia aurita in the Inland Sea of Japan. Journal of Plankton Research 27: 237-248.

West, E. J., D. T. Welsh \& K. A. Pitt, 2008. Influence of decomposing jellyfish on the sediment oxygen demand and nutrient dynamics. Hydrobiologia. doi:10.1007/ s10750-008-9586-7.

Witt, M. J., A. C. Broderick, D. J. Johns, C. Martin, R. Penrose, M. S. Hoogmoed \& B. J. Godley, 2007. Prey landscapes help identify potential foraging habitats for leatherback turtles in the NE Atlantic. Marine Ecology Progress Series 337: 231-243. 